\title{
The Use of Microfabrication Techniques for the Design and Manufacture of Artificial Stem Cell Microenvironments for Tissue Regeneration
}

\author{
David H. Ramos-Rodriguez ${ }^{1,2}{ }^{(}$, Sheila MacNeil ${ }^{2}$, Frederik Claeyssens ${ }^{2}{ }^{(\mathbb{D}}$ and Ilida Ortega Asencio ${ }^{1, *(\mathbb{D})}$ \\ 1 Bioengineering and Health Technologies Group, The School of Clinical Dentistry, University of Sheffield, \\ Sheffield S10 2TA, UK; dhramosrodriguez1@sheffield.ac.uk \\ 2 Biomaterials and Tissue Engineering Group, Department of Materials Science and Engineering, \\ Kroto Research Institute, University of Sheffield, Sheffield S3 7HQ, UK; s.macneil@sheffield.ac.uk (S.M.); \\ f.claeyssens@sheffield.ac.uk (F.C.) \\ * Correspondence: i.ortega@sheffield.ac.uk; Tel.: +44-(0)1142-159-382
}

check for updates

Citation: Ramos-Rodriguez, D.H.; MacNeil, S.; Claeyssens, F.; Asencio, I.O. The Use of Microfabrication

Techniques for the Design and

Manufacture of Artificial Stem Cell Microenvironments for Tissue Regeneration. Bioengineering 2021, 8 , 50. https://doi.org/10.3390/ bioengineering 8050050

Academic Editor: Lay Poh Tan

Received: 24 March 2021

Accepted: 21 April 2021

Published: 23 April 2021

Publisher's Note: MDPI stays neutral with regard to jurisdictional claims in published maps and institutional affiliations.

Copyright: (c) 2021 by the authors. Licensee MDPI, Basel, Switzerland. This article is an open access article distributed under the terms and conditions of the Creative Commons Attribution (CC BY) license (https:/ / creativecommons.org/licenses/by/ $4.0 /)$.

\begin{abstract}
The recapitulation of the stem cell microenvironment is an emerging area of research that has grown significantly in the last 10 to 15 years. Being able to understand the underlying mechanisms that relate stem cell behavior to the physical environment in which stem cells reside is currently a challenge that many groups are trying to unravel. Several approaches have attempted to mimic the biological components that constitute the native stem cell niche, however, this is a very intricate environment and, although promising advances have been made recently, it becomes clear that new strategies need to be explored to ensure a better understanding of the stem cell niche behavior. The second strand in stem cell niche research focuses on the use of manufacturing techniques to build simple but functional models; these models aim to mimic the physical features of the niche environment which have also been demonstrated to play a big role in directing cell responses. This second strand has involved a more engineering approach in which a wide set of microfabrication techniques have been explored in detail. This review aims to summarize the use of these microfabrication techniques and how they have approached the challenge of mimicking the native stem cell niche.
\end{abstract}

Keywords: microfabrication; microtopographies; stem cell microenvironment; tissue regeneration

\section{Introduction}

Stem cells are ideal candidates to be used in regenerative medicine applications due to their perpetual self-renewal capabilities and their ability to differentiate into specific tissue types. The three main categories of stem cells (according to their origin) are embryonic, fetal, and adult stem cells. There are significant ethical burdens associated with the use of embryonic or fetal stem cells which are related to medical regulations and consents as well as clinical challenges associated with the control of stem cell fate [1,2]. Adult stem cells, however, overcome some of these challenges since they present limited capacity to differentiate, and they are present in mature tissues and can be accessed with full and informed consent from the donors.

To fully understand and control adult stem cell behavior it is imperative to also study the spatial, mechanical, and topographical cues that are present in the adult stem cell native microenvironment (stem cell niche) [3,4].

Over the last decades, the introduction of micro and nano topographies within tissue engineering constructs (for example microgrooves, nanopits, and micropillars) has demonstrated a significant effect in guiding and controlling cell behavior; it has been reported that changes in cytoskeletal distribution and alignment of the cells have been proved to modulate several aspects of cell function and tissue regeneration, including protein production, cell fate, and proliferation $[5,6]$. 
Understanding and controlling the stem cell microenvironment opens the door to a broad new range of applications in the healthcare sector not only based on the possibility of creating innovative analytical tools and drug screening models, but in the field of regenerative medicine. With the development of novel biomaterials and manufacturing techniques, tissue engineers have now the tools to create new devices that can provide structural, chemical, and biological cues similar and mimic closer to the stem cell native environment.

In order to address the difficult and challenging task of mimicking the complexity of the stem cell niche, scientists have followed different strategies that can be divided into two main groups: (1) Mimicking metabolic behavior and biological interactions and (2) mimicking micro-nano architecture and spatial/geometrical control. This review is focused on describing the different manufacturing and microfabrication techniques used to date for the development of stem cell niche microenvironments by mimicking its spatial organization. However, a brief summary of efforts focusing on mimicking the molecular environment (1) is also included. Before discussing how microfabrication techniques have contributed to the development of synthetic niche-like environments it is important to define the stem cell niche and identify why it is important to introduce the stem cell niche concept within biomaterial design.

\section{The Adult Stem Cell Microenvironment}

Adult stem cells are considered multipotent cells as they only differentiate to cell types related to the tissue in which they reside. Types of adult stem cells include neural, hematopoietic, mesenchymal, and epidermal. After birth, somatic, germline, and adult stem cell populations reside in defined microenvironments called stem cell niches, which provide protection and use physical proximity and extracellular cues to regulate maintenance and function $[7,8]$.

The components of a prototype niche can be grouped in structural (physical) or biochemical (Figure 1). The 3D environment of a stem cell niche is believed to (i) provide a well-defined space that allows a certain degree of physical protection, (ii) supply distinctive and crucial extracellular matrix (ECM) components to accommodate a cell population with stem cell capacity and (iii) allow the presence of stromal cells and specific soluble factors $[9,10]$.

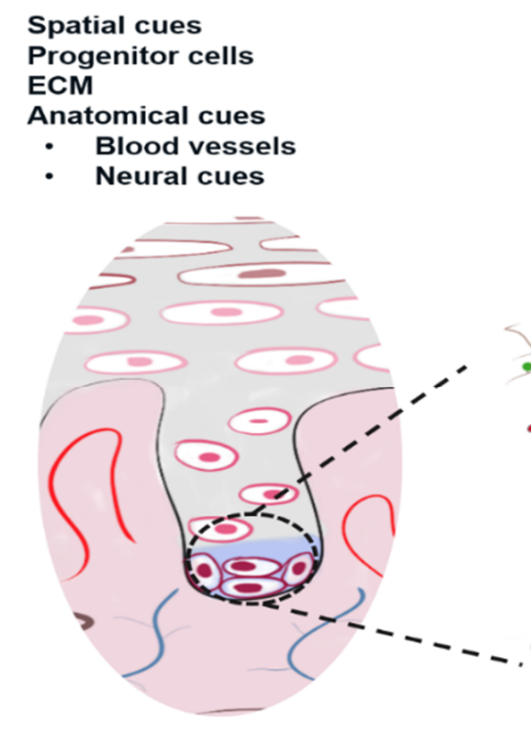

Microenvironment
- Cell-cell interactions

- CAM's

- Cadherins

- Immobilized cues

- Laminin

- GAGs

- Soluble cues

- Cytokines

- Metabolic products

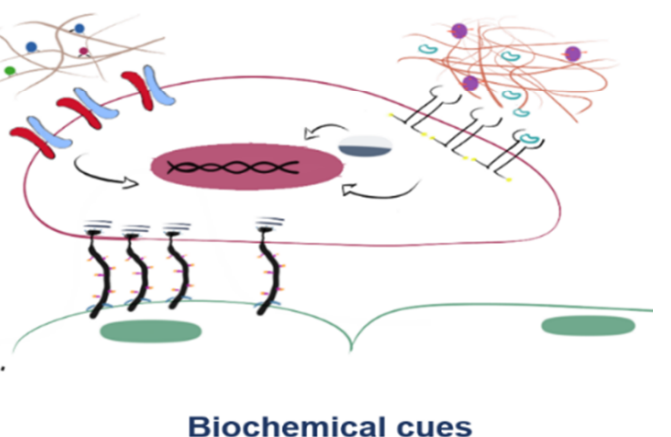

Biochemical cues

Figure 1. Biochemical and microenvironmental cues of a prototypical stem cell niche. Adapted with permission from ref. [9]. Copyright Lutolf \& Blau's Name. 
The existence of the cell niche as a physiological microenvironment that supports stem cells was proposed and defined in 1978 [11]. However, the relation between the structure of the niche and how it affects stem cell behavior was first described two decades later by using genetic model systems such as Caenorhabditis elegans [12] and Drosophila [13,14].

The structural and biochemical cues present in the stem cell niche provide key signals that control stem cell fate and protect stem cells from death or exhaustion. The microenvironment created by the niche encourages a series of close-range signals such as $\mathrm{pH}, \mathrm{ECM}$ components, and their binding to integrin transmembrane proteins, and soluble proteins. These niche signals are tissue specific and require a specific spatial distribution to maintain their function. The niche can also react to mechanical and metabolic stimuli to induce specific stem cell function [15]. The cellular organization is critical to the function of the niche, as autocrine and paracrine signals from the stem cell population and cell-cell contact influence stem cell activity [16]. Figure 2 shows the environmental factors that can influence stem cell fate.

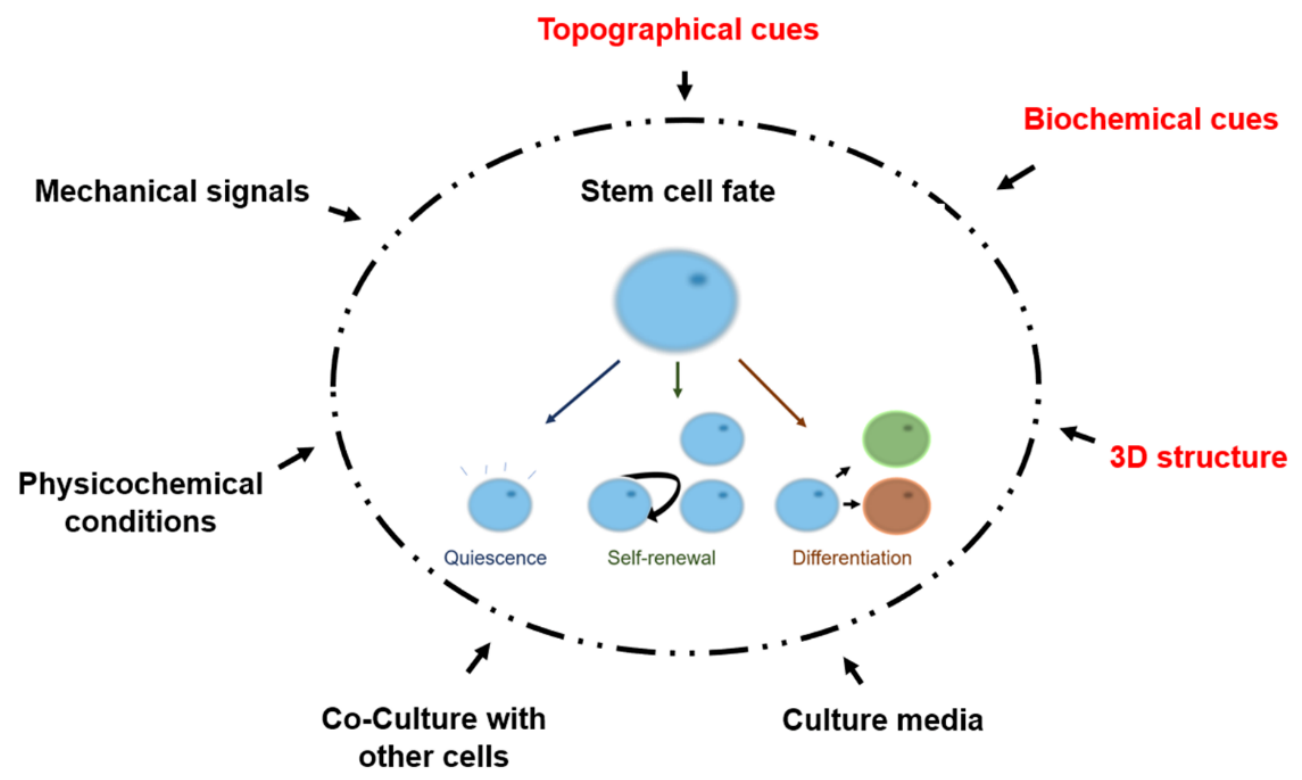

Figure 2. Schematic representation of environmental factors that affect stem cell fate. The factors highlighted in red are discussed in this review. Mechanical signals although intrinsically related to spatial distribution and topography are not covered in this review. Adapted with permission from ref. [15]. Copyright 2003. Copyright Jiang and Papoutsakis's Name.

Several studies have shown the impact of aged and deregulated stem cell niches in vivo, suggesting a relation between the loss or disruption of the stem cell niche (and the systemic factors expressed by the niche) with pathologies associated with tissue regeneration, premature aging, and tumorigenesis [17-19]. Moreover, the organization of the stem cell niche has been proposed to protect the stem cells from the accumulation of gene mutations that may lead to malignant transformation [20].

The low accessibility of the stem cell niches has limited their study in humans, where the location and regulation mechanism of most stem cell niches remains elusive. Nonetheless, stem cell niches located in the bone marrow, hair follicles in the skin, and the small intestine are particularly interesting for their role in stem cell fate and tissue regeneration. Table 1 summarizes the tissues, their niches, and stem cell populations that have been studied for their importance to regulate tissue regeneration. 
Table 1. Stem cell niches which have been studied for their potential to improve tissue regeneration by controlling stem cell behavior.

\begin{tabular}{|c|c|c|c|}
\hline Tissue/System & Location & Stem Cell Population & Ref \\
\hline \multirow{3}{*}{ Skin } & Hair follicles & $\begin{array}{l}\text { Melanocyte stem cells, Hair } \\
\text { follicle dermal papilla cells }\end{array}$ & {$[21,22]$} \\
\hline & \multirow{2}{*}{ Rete ridges } & Epidermal stem cells & [23] \\
\hline & & Keratinocyte stem cells & {$[24]$} \\
\hline \multirow{2}{*}{$\begin{array}{l}\text { Hematopoietic } \\
\text { system }\end{array}$} & \multirow{2}{*}{ Bone marrow } & $\begin{array}{l}\text { Hematopoietic stem } \\
\text { cells (HSCs) }\end{array}$ & [25] \\
\hline & & $\begin{array}{l}\text { Mesenchymal stem } \\
\text { cells (MSC) }\end{array}$ & [26] \\
\hline Small intestine & $\begin{array}{l}\text { Epithelium of the small } \\
\text { intestine }\end{array}$ & $\begin{array}{c}\text { Intestinal stem cells, } \\
\text { non-epithelial stromal cells, } \\
\text { myofibroblasts. }\end{array}$ & [27] \\
\hline \multirow{2}{*}{ Heart } & Epicardial lining & \multirow{2}{*}{ Cardiac stem cells (CSC) } & \multirow{2}{*}{ [28] } \\
\hline & Myocardium & & \\
\hline Cartilage & Articular cartilage & $\begin{array}{c}\text { Bone marrow Mesenchymal } \\
\text { stem cells (BMSC), } \\
\text { Cartilage-derived } \\
\text { mesenchymal progenitors }\end{array}$ & [29] \\
\hline Eye & $\begin{array}{c}\text { Corneal } \\
\text { limbus/Palisades of Vogt }\end{array}$ & Limbal epithelial stem cells & [30] \\
\hline \multirow[b]{2}{*}{ Neural system } & Subventricular zone & Neuronal stem cells (NSC) & {$[31,32]$} \\
\hline & $\begin{array}{l}\text { Hilus of the } \\
\text { dentate gyrus }\end{array}$ & $\begin{array}{c}\text { Radial neural stem cells, } \\
\text { Dentate gyrus neural } \\
\text { stem cells }\end{array}$ & {$[33]$} \\
\hline Lung & $\begin{array}{l}\text { Lung } \\
\text { epithelium/tracheal } \\
\text { submucosal glands }\end{array}$ & $\begin{array}{c}\text { Basal cells, club cells, and } \\
\text { alveolar epithelial cells } \\
\text { type II cells. }\end{array}$ & {$[34,35]$} \\
\hline $\begin{array}{c}\text { Primary or } \\
\text { permanent teeth }\end{array}$ & Dental pulp tissue & $\begin{array}{l}\text { Human dental pulp stem } \\
\text { cells, MSCs, BMSCs. }\end{array}$ & {$[36,37]$} \\
\hline
\end{tabular}

Changes in composition or distribution could disrupt the balance of cell renewal and compromise the lifespan of the tissue. Systems that require a high proliferation and continuous replenishment of cells, such as the epidermis, intestine, cornea, or hematopoietic system, have a need for active stem cell niches that can supply this high self-renewal cycle [38-41].

In comparison, tissues such as the skeletal muscle or the endoskeletal region require a dormant stem cell niche that can preserve a quiescent stem cell population [17-42]. This behavior can be observed in epithelial stem cells where the proliferative potential, physical protection, and undifferentiated phenotype are defined by the microenvironments present on the corneal limbus, hair bulge, epidermal layer, or at the bottom of the rete ridges [21].

Although micro and nano topographical cues have been introduced within biomaterial constructs to provide substrates to mimic cell-cell and cell-niche interactions, the reality is that recreating the stem cell niche microenvironment remains a big challenge [5-43] and the currently available tissue engineering scaffolds fail to recreate the native tissues either at micro or nanostructural levels.

As highlighted in the introductory section, the main strategies reported in the literature that aim to recreate stem cell niches can be grouped into two distinct categories: (a) introducing complexity into tissue engineered scaffolds by mimicking to a certain extent the natural spatial/physical microfeatures and (b) mimicking the complex biological components that influence cellular metabolic behavior and molecular interactions. 


\section{Mimicking Biological Components of the Stem Cell Microenvironment}

The study of the molecular components of the stem cell niche has been critical to understanding the mechanisms involved in stem cell regulation. Studies with Drosophila have shown an intrinsic relationship between acellular components produced in the niche and stem cell homeostasis [44,45].

The initial attempts to recreate to a certain extent the stem cell niche started with deconstructing the biochemical cues of the niche. Introduction of ligands and peptides, changes in matrix composition and mechanical properties, co-culture with stromal support cells, and addition of soluble factors (chemokines, cytokines, and growth factors) have been some of the strategies used to mimic the complexity of the stem cell niche $[17,46]$.

The ECM of the stem cell niche has been the main focus to replicate due to its importance in controlling cell behavior through cell receptors, signaling molecules, structural proteins, glycoproteins [47], enzymatic remodeling, metabolic products, and growth factors [48]. Cells interact with the ECM to form adhesion to the nanometric fibers that mostly constitute the extracellular topographical environment [49]. These interactions are controlled by integrins, transmembrane proteins, and their binding to specific amino acid sequences such as the RGD sequence found in fibronectin [50,51].

The role of integrin and non-integrin receptors have been explored due to their role in homing, adhesion, anchoring, proliferation, differentiation, survival, and migration on stem cell microenvironments [52-55].

However, most of these receptors have yet to be introduced into scaffolds. Early attempts at mimicking a functional hematopoietic stem cell niche were published by Sharma et al. in 2012, using co-cultured mesenchymal stromal cells and CD34+ cells introduced into hydrogels to influence stem cell phenotype and functional parameters [56]. Comprehensive reviews of the methodologies used to study the biological components of the adult stem cell niche were presented by Lutolf et al. [9,57].

Biomolecular patterning is a promising approach to create gradients of biochemical cues on surfaces that can later be introduced into spatial cues to create a complex microenvironment. Protein microarrays, on-chip microdroplets, and biomolecular patterning are recent platform technologies that are being used to introduce molecular complexity within scaffolds and to study how stem cells behave in vitro [57].

\section{Mimicking the Spatial and Physical Components of the Stem Cell Microenvironment}

Using microfabrication techniques such as additive manufacturing and soft-lithography scientists have been able to create complex arrays and architectures that were not possible before. Microfabrication techniques involve the construction of structures, patterns, or topographies that range in the micrometric scale (or nanometric for several applications). The first attempts at controlling and understanding the relation of spatial distribution and cell behavior started with the introduction of fibrous environments to mimic the ECM $[58,59]$.

Initial studies have proved that micro-interactions and nanotopography can affect stem cell mechanotransduction through focal adhesion interactions [60], as well as introducing spatial cues that change the distribution of stem cells that regulate stem cell division.

A key factor in selecting a microfabrication technique is considering the nature of the material to be used since chemical functionality, degradation rate/by-products, surface energy, nanotopography, and stiffness, can induce or inhibit specific pathways that control stem cell fate $[61,62]$.

Fabrication techniques that have been used to replicate spatial cues of stem cell microenvironment include soft-lithography (using electron-beam and photolithography), patterned hydrogels, laser-based methods, and electrospinning.

\subsection{Soft-Lithographic Methods}

Soft lithography is a family of fabrication techniques that uses elastomeric stamps, molds, and conformable photomasks, that range from micrometer to nanometer scale 
to create patterned surfaces [63]. The stamp is generally prepared by casting the liquid pre-polymer of an elastomer material against a master material that has been created via traditional lithographic techniques such as photolithography or stereolithography (SLA) [64] and thus is limited by the resolution of the method chosen to create the stamp. In some of these studies, $\mu$ SLA is used which refers to building high resolution $(100 \mathrm{~nm}-10 \mu \mathrm{m})$ structures with stereolithography and related techniques such as $2 \mathrm{PP}$. Controlling the peeling rate and selecting a proper patterning technique is critical to avoid deforming the stamp or crushing the printed pattern [65,66]. Micro-contact printing [67], replica molding [68], solvent-assisted micromolding [69], and micromolding in capillary [70] are stamping techniques that have been used to preserve micro topographical cues for cell culture. Figure 3 shows the general fabrication method for soft lithography patterned surfaces.

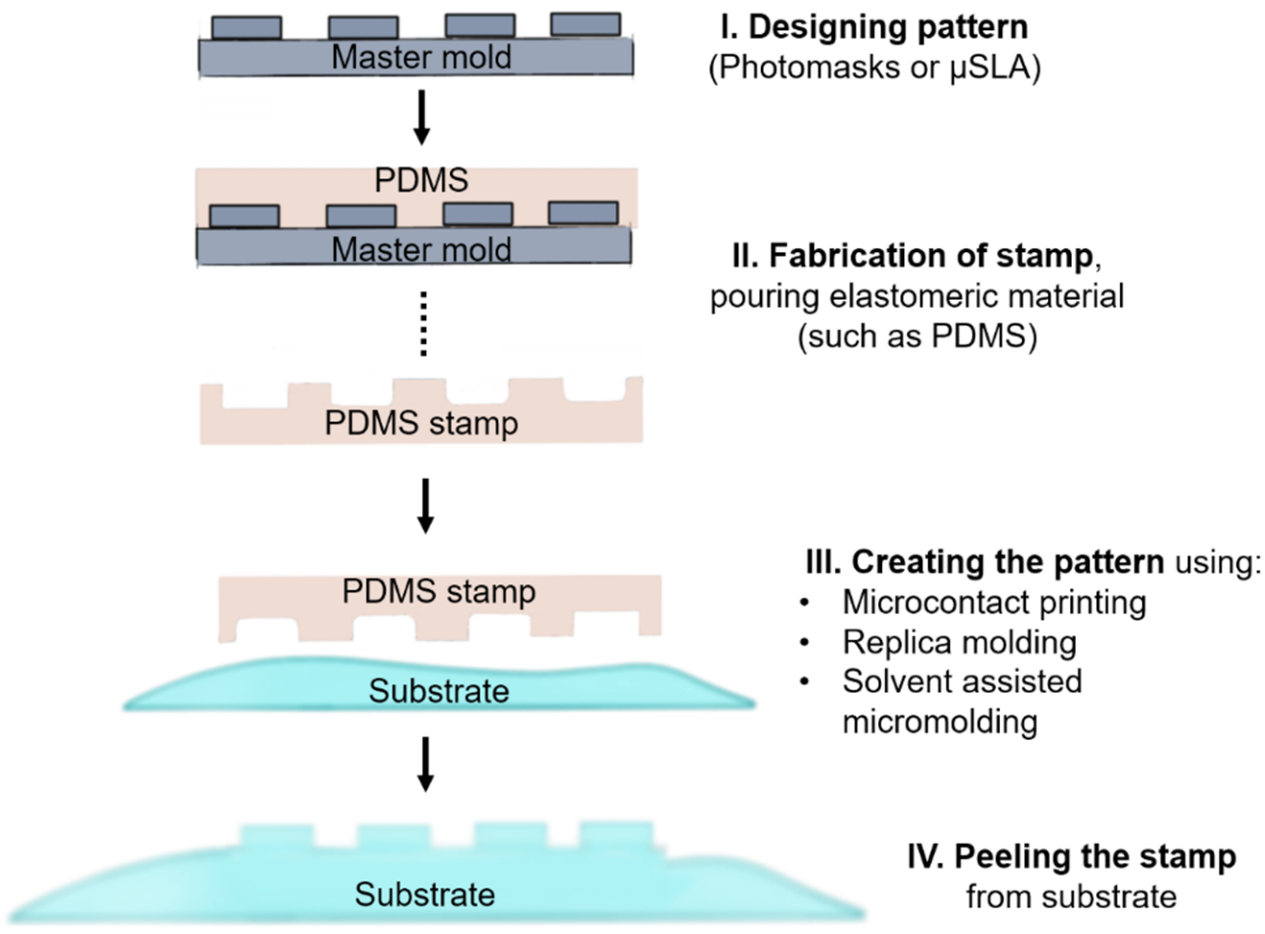

Figure 3. Soft lithography fabrication diagram. First, a master mold is created normally using a silicon wafer. The CAD pattern is printed on the surface of the master mold using $\mu$ SLA. Once completed, the elastomeric material is poured, and a stamp is created. This stamp is used to create a pattern on the substrate surface. The patterning technique depends on the selected substrate, which is chosen according to the application. Finally, the stamp is peeled from the substrate.

Advanced photolithographic techniques have been raised to overcome the resolution limitation. Electron-beam lithography (eBL) uses a narrow beam of electrons over an electron-sensitive material allowing for a lateral high resolution of 3-5 $\mathrm{nm}$ [71], higher than the $1 \mu \mathrm{m}$ resolution of standard photolithography The high resolution of eBL has been used to study populations of undifferentiated MSCs seeded on nanotopograhical cues from 120-500 nm [72-74].

The polymer PDMS is the standard material to create the stamp due to its elasticity, hydrophobicity, biocompatibility, and optical transparency [75]. Nonetheless, it is possible to transfer the pattern using other elastomeric materials such as polyurethane, polyamide, phenol-formaldehyde polymers, and specific siloxane polymer formulations for highresolution applications $[76,77]$. Synthetic and non-synthetic biomaterials can be used in this technique to create micro or nanostructures to study cell behavior. Materials such as poly(ethylene glycol) (PEG) [78], poly(lactic-co-glycolic acid) (PLGA) [79,80], collagen [81], and elastin are commonly used to either functionalize the PDMS stamp or as a casting 
material. Although soft-lithographic stamps can be used directly for cell culture, the functionalization of the stamp is required to achieve appropriate cell adhesion.

The most common approach for soft lithography in tissue engineering is casting the PDMS pattern on a polymer with surface properties more suitable for cell culture or that possesses specific biochemical and mechanical properties for the desired application. It is also possible to load the PDMS stamp with the relevant biomolecules that are then printed on the surface of the cast polymer [82], creating a "hybrid" scaffold that combines biomolecular patterning and spatial cues to mimic the stem cell microenvironment.

Table 2 shows some of the work that has been done to replicate and study the stem cell microenvironment using soft lithography. The initial attempts of introducing topographical cues to stem cell cultures were done by using patterned surfaces created by lithographic techniques without further functionalization $[83,84]$. Further developments in stem cell research showed the importance of introducing substrates that encourage rapid stem cell attachment to avoid undesired differentiation [85-87]. This led to the use of stiff biocompatible substrates that can later be functionalized with surface modification techniques or by a bioactive coating [88].

Table 2. Summary of soft-lithographic constructs used to recreate the micro and nano spatial cues of the stem cell niche.

\begin{tabular}{|c|c|c|c|}
\hline Application & Polymer & Outcome & Ref \\
\hline $\begin{array}{l}\text { Study MSC fate and } \\
\text { neurosphere formation. }\end{array}$ & $\begin{array}{l}\text { PDMS mold cast on } \\
\text { PEG hydrogel. }\end{array}$ & $\begin{array}{l}\text { 96-well plate structure. Each well is } \\
\text { composed of } 33 \times 33 \text { microwells of } \\
100 \mu \mathrm{m} \text { diameter. }\end{array}$ & {$[78]$} \\
\hline Observe retinal progenitor cell behavior. & $\begin{array}{l}\text { PDMS mold cast on PLGA } \\
75: 25 \text { substrate. }\end{array}$ & $\begin{array}{l}\text { Microchannels of } 15 \mu \mathrm{m} \text { diameter and } \\
40 \mu \mathrm{m} \text { height. }\end{array}$ & [80] \\
\hline $\begin{array}{c}\text { Assess the effects of ridges and grooves } \\
\text { on hMSCs differentiation } \\
\text { and proliferation. }\end{array}$ & $\begin{array}{l}\text { PDMS stamp cast on } \\
\text { NOA81 polyurethane }\end{array}$ & $\begin{array}{l}\text { Microgrooves of } 300 \mathrm{~nm} \text { in depth and } \\
400,1400 \text {, or } 4000 \mathrm{~nm} \text { pitch. }\end{array}$ & [89] \\
\hline $\begin{array}{l}\text { Study keratinocyte stem cell niches of the } \\
\text { dermal-epidermal junction }\end{array}$ & $\begin{array}{l}\text { Collagen type I pour on PDMS } \\
\text { mold. Collagen was then } \\
\text { conjugated with fibronectin }\end{array}$ & $\begin{array}{l}\text { Multilayer constructs with a series of } \\
200 \mu \mathrm{m} \text { deep channels with variable } \\
\text { widths of } 50,100,200 \text {, and } 400 \mu \mathrm{m} \text {. }\end{array}$ & [90] \\
\hline $\begin{array}{l}\text { Analyze the response of hHSC and } \\
\text { progenitor cells to specific spatial and } \\
\text { biochemical cues. }\end{array}$ & $\begin{array}{l}\text { PDMS stamp cast on } \\
\text { starPEG-heparin hydrogels. }\end{array}$ & $\begin{array}{l}\text { Grooves, rings, and cubes from } \\
\qquad 2-500 \mu \mathrm{m} .\end{array}$ & [69] \\
\hline $\begin{array}{l}\text { Create a bilayered hydrogel dressing to } \\
\text { induce revascularization and } \\
\text { re-epithelialization. }\end{array}$ & $\begin{array}{c}\text { Platinum-catalyzed PDMS cast on } \\
\text { gelatin hydrogels. }\end{array}$ & $\begin{array}{l}\text { Sharklet }{ }^{\mathrm{TM}} \text { micropatterns of } 1 \mu \mathrm{m} \\
\mathrm{H}-10 \mu \mathrm{m} \mathrm{W} \text { and } 10 \mu \mathrm{m} \mathrm{H}-50 \mu \mathrm{m} \mathrm{H} \text {. }\end{array}$ & [91] \\
\hline $\begin{array}{l}\text { Study the effects of nanotopograhical } \\
\text { cues on hMSCs osteogenesis. }\end{array}$ & $\begin{array}{l}\text { UV curable polyurethane acrylate } \\
\text { coated with gelatin. }\end{array}$ & $\begin{array}{l}\text { Nanoscale dots of } 150 \text {, } \\
400 \text {, and } 600 \mathrm{~nm} \text { diameter and lines of } \\
150,400 \text {, and } 600 \mathrm{~nm} \text { width. }\end{array}$ & [92] \\
\hline $\begin{array}{l}\text { Create dermal-epidermal regeneration } \\
\text { matrices with microfeatures to mimic the } \\
\text { DEJ and to study their effect on basal } \\
\text { keratinocyte functions. }\end{array}$ & $\begin{array}{l}\text { PDMS mold on stamped on } \\
\text { collagen I-GAG gel, conjugated } \\
\text { with fibronectin. }\end{array}$ & $\begin{array}{l}\text { Micro channels with a depth of } \\
200 \mu \mathrm{m} \text { and widths of 50,100,200, } \\
\text { and } 400 \mu \mathrm{m} .\end{array}$ & [93] \\
\hline $\begin{array}{l}\text { Investigate the effects of micro spatial } \\
\text { cues on adipose-derived stem } \\
\text { cells differentiation. }\end{array}$ & $\begin{array}{l}\text { PDMS molds on a collagen-silk } \\
\text { fibroin substrate. }\end{array}$ & $\begin{array}{l}\text { Microchannel and micropillar } \\
\text { patterns of } 10 \mu \mathrm{m} \text { and } \\
8 \mu \mathrm{m} \text { respectively. }\end{array}$ & [94] \\
\hline $\begin{array}{l}\text { To culture neonatal human fibroblasts } \\
\text { (NHFs) to study the dermal papillae. }\end{array}$ & $\begin{array}{l}\text { PDMS mold cast on Gelatin- } \\
\text { chondroitin-6-sulfate-hyaluronic } \\
\text { acid substrate. }\end{array}$ & $\begin{array}{l}\text { Undulated microtopographies that } \\
\text { range from } 150-450 \mu \mathrm{m} \text { height and } \\
364-1062 \mu \mathrm{m} \text { width. }\end{array}$ & [95] \\
\hline $\begin{array}{l}\text { Characterize the effects of topographical } \\
\text { cues on primary human keratinocytes. }\end{array}$ & $\begin{array}{l}\text { PDMS patterns coated with } \\
\text { collagen type I. }\end{array}$ & $\begin{array}{l}\text { Patterned substrates with } \\
\text { undulations that range from } 100 \text { to } \\
300 \mu \mathrm{m} \text {. }\end{array}$ & [96] \\
\hline $\begin{array}{l}\text { Study the effects of surface treatment and } \\
\text { microgrooves on rat dermal fibroblasts. }\end{array}$ & $\begin{array}{l}\text { PDMS molds treated with UV, } \\
\text { RFGD, or a combination of both. }\end{array}$ & $\begin{array}{c}\text { Square grooved surface with features } \\
\text { of } 2,5 \text {, or } 10 \mu \mathrm{m} \text { width and } \\
0.5 \mu \mathrm{m} \text { depth. }\end{array}$ & [97] \\
\hline $\begin{array}{l}\text { Study the effect of surface topography on } \\
\text { abdomen fibroblasts. }\end{array}$ & PDMS mold. & $\begin{array}{l}\text { Square wells with micro } \\
\text { topographical cues of } 2,5 \text {, or } 10 \mu \mathrm{m} \text {. }\end{array}$ & [83] \\
\hline
\end{tabular}


Soft lithography has been widely used due to the variety of available materials, versatility when designing the micropattern, and relatively low cost $[65,98]$. However, generating angled surfaces, and producing densely arrayed patterns for nanometric applications remain challenges for conventional soft lithography [68,99]. In vivo applications of this fabrication technique are limited. This can be related to the poor biodegradable and/or biocompatible characteristics of the most common substrate materials.

It is important to consider that the extracellular fibrous environment in the stem cell niche is key for nutrient diffusion, extracellular signals, and cell migration. However, most soft-lithography applications recreate the micro or nano spatial cues on solid 2D substrates. This means that the constructs created with this technique have low to no cell infiltration potential and cannot replicate the 3D fibrous environment of the ECM or the porous structure of hard tissues. To improve cell infiltration and thus tissue integration and construct survivability, collagen has been incorporated into soft-lithographic applications either by coating the elastomeric mold or as the cast material [94,100].

Although it is possible to use a conventional PDMS stamp on a hydrogel substrate, the physical properties of the hydrogel require different considerations from those that a solid substrate to preserve the microstructure of the pattern. In recent years, advanced soft-lithographic micropattern techniques have been developed to create high-resolution and high-throughput microfluidic scaffolds and patterned hydrogels.

\subsubsection{Patterned Hydrogels}

Hydrogels are defined by their 3D polymeric environment and their hydrophilic nature capable of holding large amounts of water. Their high biocompatibility and versatile biodegradability have made hydrogels excellent biomaterials to be used as drug delivery devices, hemostasis bandages, biosensors, and carriers for cells in tissue engineering [101]. Although hydrogels can be fabricated from synthetic and natural polymers, synthetic polymers have become more relevant due to their long service life, high mechanical strength, and higher water absorption [102]. Relevant hydrogel materials used to culture stem cells include PEG [103], poly(2-hydroxyethyl methacrylate) (HEMA) [104] elastin [105], collagen [106], and hyaluronic acid [107].

Hydrogels are commonly fabricated by copolymerization or crosslinking free-radical polymerizations inducing hydrophilic monomers to react and form a network [102]. Their 3D spatial network of polymeric chains made hydrogels a promising alternative to recreate the stem cell microenvironment ECM. Because the cross-linking density alters the stiffness of the hydrogel, it is possible to study the relation between the mechanical properties of the substrate and stem cell behavior [108,109].

Collagen hydrogels are examples of natural polymers used to recreate the ECM's physical and chemical components $[110,111]$. Other natural materials used to fabricate hydrogels include fibrin, gelatin, alginate, and hyaluronic acid. Hydrogels made with these natural materials can promote cell adhesion due to the presence of bioactive sequences that interact with protein receptors [112]. Bioactive modifications of synthetic hydrogels can enhance cell attachment and proliferation by introducing Arg-Gly-Asp (RGD) peptide sequences, growth factors, ECM-derived short peptides, and proteoglycans [113].

Conventional hydrogels introduce a nanometric 3D network but lack the microarchitecture present in the stem cell niche. The need to recreate both the 3D environment and topographical cues lead to the development of several fabrication methods, aiming to introduce micro/nano spatial cues without compromising the chemistry and mechanical properties of the hydrogel. These techniques include: glass slide nanopatterning by blockcopolymer micelle nanolithography (BCMN) [114,115], multilayer soft-lithography [116], Real Architecture For 3D Tissue (RAFT ${ }^{\mathrm{TM}}$ ) $[117,118]$, and capillary force lithography (CFL) [119]. Table 3 shows examples of patterned hydrogels fabricated to replicate the stem cell microenvironment. 
Table 3. Summary of pattern hydrogel constructs used to recreate the micro and nano spatial cues of the stem cell niche.

\begin{tabular}{|c|c|c|c|}
\hline Application & Polymer & Outcome & Ref \\
\hline $\begin{array}{l}\text { Mimic the ECM 3D structured of BMSCs } \\
\text { to study cell-matrix interactions. }\end{array}$ & $\begin{array}{l}\text { Photocrosslinked } \\
\text { collagen hydrogel. }\end{array}$ & $\begin{array}{l}\text { Porous network collagen hydrogels. } \\
\text { Average pore size of } 0.3-0.7 \mu \mathrm{m} \text { and } \\
\text { average fiber size }<100 \mathrm{~nm} \text {. }\end{array}$ & [120] \\
\hline $\begin{array}{l}\text { Replicate the structural and biochemical } \\
\text { cues of the bone marrow } \\
\text { microenvironment in vitro. }\end{array}$ & $\begin{array}{l}\text { PEG- diacrylate hydrogel loaded } \\
\text { with relevant niche biomolecules. }\end{array}$ & $\begin{array}{l}\text { Functionalized microwells of } 500 \mu \mathrm{m} \\
\text { depth and } 5.34 \mathrm{~mm} \text { in diameter. }\end{array}$ & $\begin{array}{l}{[103,} \\
121]\end{array}$ \\
\hline $\begin{array}{l}\text { Develop a platform to study how hHSC } \\
\text { behaves when exposed to ligands } \\
\text { expressed in their microenvironment. }\end{array}$ & $\begin{array}{l}\text { PEG-diacrylate and RGD } \\
\text { modified PEG acrylate hydrogel. }\end{array}$ & $\begin{array}{l}\text { Hexagonally ordered arrays of } \\
\text { homogeneously distributed gold } \\
\text { nanoparticles. An interparticle } \\
\text { distance of } 40 \text { and } 90 \mathrm{~nm} .\end{array}$ & [115] \\
\hline $\begin{array}{c}\text { Observe the cellular behavior of hASCs } \\
\text { exposed to a 3D } \\
\text { micropattern environment. }\end{array}$ & $\begin{array}{l}\text { Dual-Crosslinked oxidized } \\
\text { methacrylated alginate-PEG } \\
\text { hydrogel using a photomask to } \\
\text { create the micropattern. }\end{array}$ & $\begin{array}{l}\text { Micro checkerboard tile patterns with } \\
\text { dimensions of } 25,50,100 \text {, or } 200 \mu \mathrm{m} \text {. }\end{array}$ & [122] \\
\hline $\begin{array}{l}\text { Create an in vitro platform that mimics } \\
\text { the native myocardial matrix of the } \\
\text { cardiac stem cell niche. }\end{array}$ & $\begin{array}{l}\text { A UV curable polyurethane } \\
\text { acrylate mold cast on a PEG } \\
\text { hydrogel using CFL. }\end{array}$ & $\begin{array}{l}\text { An array of ridges with } 400 \mathrm{~nm} \text { width } \\
\text { and } 500 \mathrm{~nm} \text { height, and grooves of } \\
400 \mathrm{~nm} \text { width. }\end{array}$ & [119] \\
\hline $\begin{array}{l}\text { Create a platform to study the effects of } \\
\text { topographical cues on 3D substrates for } \\
\text { hMSCs and hiPSCs }\end{array}$ & $\begin{array}{l}\text { Alginate-gelatin and } \\
\text { к-carrageenan hydrogels created } \\
\text { using micropatterned wax molds }\end{array}$ & $\begin{array}{l}1000 \mu \mathrm{m} \text { circular projections with } 400 \\
\mu \mathrm{m} \text { channels and } 1500 \mu \mathrm{m} \text { circular } \\
\text { projections with } 600 \mu \mathrm{m} \text { channels, } \\
\text { and square grids of } 620 \mu \mathrm{m} \text {, ridges of } \\
330 \mu \mathrm{m} \text { and channels of } 270 \mu \mathrm{m} .\end{array}$ & [123] \\
\hline $\begin{array}{l}\text { Study the interactions of limbal epithelial } \\
\text { stem cells inside bioengineered } \\
\text { limbal crypts }\end{array}$ & $\begin{array}{l}\text { Hydrophilic porous absorbers } \\
\text { with microtopographies on } \\
\text { collagen I hydrogels } \\
\text { using RAFT } \\
\text { TM }\end{array}$ & $\begin{array}{l}\text { Micro ridges of equal depths and } \\
\text { widths of } 100,150,200 \text {, or } 250 \mu \mathrm{m} \text {. }\end{array}$ & [117] \\
\hline
\end{tabular}

In comparison with conventional soft-lithographic methods, fabricating patterned hydrogels is a longer and more complex procedure, especially for biofunctionalized hydrogels. Although it is possible to use hydrogels as a substrate for soft-lithography, soft hydrogels are usually damaged by conventional demolding or curing steps [123]. However, a microstructured hydrogel construct is arguably more efficient in recreating the stem cell microenvironment spatial cues as it incorporates a 3D nanometric network as well as a 2D patterned surface that can mimic specific niche architectures. Because of their high biocompatibility, hydrogels are commonly implemented for in vivo applications to reintroduce stem niche-like structures on damaged tissue $[119,120]$.

Stimuli-responsive hydrogels are yet to be tested as a platform to introduce micro topographical cues and study the components and mechanism of stem cell niches. However, they are a promising approach to study adult stem cells in a dynamic physical and chemical microenvironment [124,125].

\subsubsection{Microfluidic Devices}

Microfluidic systems are based on the control of fluids in a micrometer to millimeter scale, allowing for precise control of soluble factors, gradients, and mechanical signals in which biological systems can be studied [126]. Microfluidic scaffolds are a promising strategy to recreate and manipulate the 3D structure of the stem cell microenvironment while dictating the distribution and flow rate of soluble biomolecules [127]. Microfluidic techniques had led to the development of high throughput cell culture systems and organon-a-chip devices [128].

Microfluidic devices make an excellent platform to study cells under various physical, chemical, and mechanical microenvironmental conditions such as stress capillary flow, 
chemical gradients, $\mathrm{pH}$, temperature, micro, and nano spatial cues, and the effects of single/low cell numbers on the temporal and spatial resolution [129-131].

Applications of microfluidic techniques were primarily used to study single-cell interactions in a controlled microenvironment that can recreate certain biologically relevant conditions. Although there is no standard procedure to fabricate a microfluidic device, common fabrication techniques include droplet-based microfluidics, micro-molding, and sacrificial layer elimination [132-135]. Microfluidic fabrication techniques have been covered extensively in other reviews $[127,134,136]$. Table 4 shows a summary of microfluidic devices fabricated to replicate certain aspects of the stem cell microenvironment.

Table 4. Summary of microfluidic devices used to recreate the micro and nano spatial cues of the cell microenvironment.

\begin{tabular}{|c|c|c|c|}
\hline Application & Polymer & Outcome & Ref \\
\hline $\begin{array}{l}\text { Create a microfabrication platform to } \\
\text { study adult NSC fate }\end{array}$ & $\begin{array}{c}\text { SU-8 photoresist material coated } \\
\text { with poly-ornithine and laminin, } \\
\text { placed on oxygen plasma treated } \\
\text { glass coverslips }\end{array}$ & $\begin{array}{c}\text { An array of microwells with } \\
\text { dimensions that ranged from } 20 \text { to } \\
500 \mu \mathrm{m} \text { in diameter and } 10-500 \mu \mathrm{m} \\
\text { in height. }\end{array}$ & [137] \\
\hline $\begin{array}{l}\text { Study the effects of 3D microenvironment } \\
\text { for NSCs on self-renewal } \\
\text { and differentiation }\end{array}$ & $\begin{array}{l}\text { PDMS surface coated with COL I } \\
\text { fabricated with a SU-8 pattern } \\
\text { master. A COL I hydrogel was } \\
\text { used as a cell carrier }\end{array}$ & $\begin{array}{l}\text { 3D collagen-coated microchannels of } \\
\qquad 140-160 \mu \mathrm{m} \text { height. }\end{array}$ & [138] \\
\hline $\begin{array}{l}\text { New fabrication approach to recreate } \\
\text { stem cell niches using hydrogel } \\
\text { engineering with droplet } \\
\text { microfluidic technology }\end{array}$ & $\begin{array}{l}\text { PDMS microfluidic bonded to } \\
\text { glass coverslips using oxygen } \\
\text { plasma. Chips were loaded with } \\
\text { functionalized PEG hydrogels. }\end{array}$ & $\begin{array}{l}\text { Microchannels array of } 100 \mu \mathrm{m} \text { deep } \\
\text { with three different channel widths of } \\
100,200 \text {, and } 300 \mu \mathrm{m} \text {. }\end{array}$ & [139] \\
\hline $\begin{array}{c}\text { Generate a high-throughput platform to } \\
\text { study the stem cell microenvironment } \\
\text { with a tunable ratio of } \\
\text { encapsulated species. }\end{array}$ & $\begin{array}{l}\text { Cell-laden agarose microgels } \\
\text { loaded into a functionalized } \\
\text { PDMS surface. }\end{array}$ & $\begin{array}{l}\text { An array of micro agarose gels of } 70 \\
\text { to } 110 \mu \mathrm{m} .\end{array}$ & [140] \\
\hline $\begin{array}{l}\text { Build functional networks that can be } \\
\text { modified during the experiment to } \\
\text { manipulate hMSC behavior in situ. }\end{array}$ & $\begin{array}{l}\text { PDMS mount to cast crosslinked } \\
\text { PED hydrogels }\end{array}$ & $\begin{array}{l}\text { Artificial blood-vessel microfluidic } \\
\text { network within cell-containing } \\
\text { hydrogels. Channel diameter can be } \\
\text { controlled in situ. }\end{array}$ & [141] \\
\hline $\begin{array}{l}\text { Create a two-layer microfluidic system to } \\
\text { culture 3D multi-cell type spheroids to } \\
\text { study cancer stem cell microenvironment. }\end{array}$ & $\begin{array}{l}\text { PDMS device separated by a } \\
\text { polycarbonate membrane and } \\
\text { treated with } 1 \% w / v \\
\text { Pluronic F108 }\end{array}$ & $\begin{array}{c}\text { A microfluidic system with a lower } \\
\text { channel of } 100 \mu \mathrm{m} \mathrm{H} \text { and } 2 \mathrm{~mm} \text { in } \mathrm{W} \text {, } \\
\text { and a central microchannel of } 200 \mu \mathrm{m} \\
\mathrm{H} \text { and } 50 \mu \mathrm{m} \text { in } \mathrm{W} .\end{array}$ & [142] \\
\hline
\end{tabular}

Although versatile in their applications, microfluidic devices required a complex setup and long fabrication process. Regarding stem cell culture, major limitations for long term applications include liquid evaporation, leaching of non-reactive compounds, hydrophobic recovery, and protein adsorption [129]. Microfluidics is a powerful tool to understand the underlying mechanism of the stem cell microenvironment, as it allows for the measure and control of relevant metabolites and the platform can be as complex as needed. Novel applications have aimed to introduce several layers of parallel reactions to mimic several adjacent mechanisms that control cell fate.

\subsection{Electrospinning-Based Methods}

Electrospinning is an advanced manufacturing technique that uses polymer solutions and an electrical potential to produce fibers from nanometer to micrometer scales. Electrospinning techniques have the potential to control fiber diameter and orientation in comparison with other techniques such as hydrogels which can be fabricated from fibrous components, but which distribution is intrinsic to the material. In comparison, electrospinning uses different setups, and changes in the solution and process parameters to generate 
specific micro and nanofibrous architectures [143]. The standard electrospinning setup is represented in Figure 4.

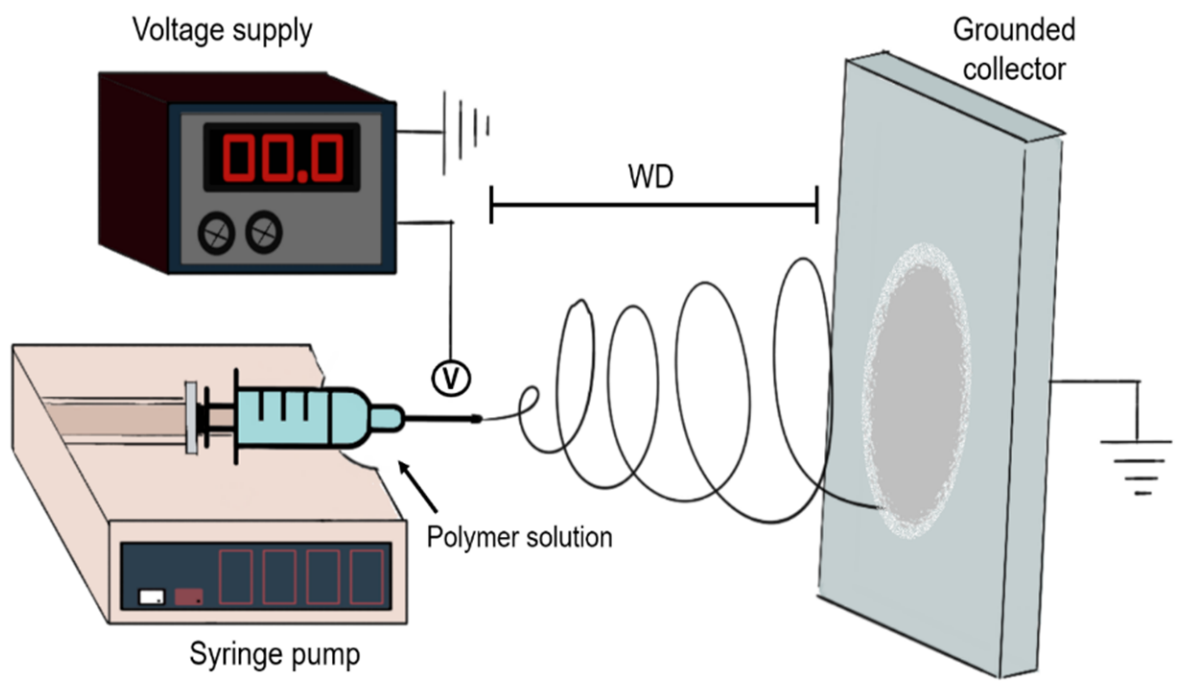

Figure 4. Diagram of the fabrication of nano/microfibers using a conventional electrospinning setup. First, a polymer solution is a pump through a capillary, commonly using a syringe pump. Then the working distance (WD) is set. The high voltage source with positive polarity is connected to the capillary and negative polarity connected to a grounded collector. As the polymer solution flows through the tip of the capillary it forms a jet that travels towards the collector.

Electrospinning fibers are fabricated by electrifying a pendant drop of polymer solution until the electrostatic charges disrupt its surface, deforming the drop and creating a conical shape known as the Taylor cone. If the voltage continues to increase over the threshold value of the polymer solution, the surface tension of the Taylor cone is disrupted creating a polymer jet that travels toward the grounded metal collector. As the polymer jet travels, the solvent evaporates and with a constant polymer flow rate, a nonwoven fibrous mat is deposited on the collector [144,145].

The process parameters (voltage, the distance between the drop and the collector, and flow rate), solution parameters (surface tension, solvent system, viscosity, solution conductivity), and environmental parameters (temperature and humidity) control the outcome of electrospinning. The general relation between these parameters has been described previously [145], but no model has been able to predict the dynamic electrospinning phenomena [143]. Meaning that all new applications should be thoroughly tested, and parameters should be refined for each application.

The relation between fiber diameter and cell migration and adhesion has been well established for primary cell lines [146,147]. The high porosity and structural properties of nanofibers have also been proved to enhance cell differentiation, adhesion, and proliferation. Synthetic and natural materials can be processed to create electrospun mats. These materials include PLGA, polylactic acid (PLA), poly(e-caprolactone) (PCL), PU, collagen, elastin, and silk [148-150]. However, for most natural polymers their low solubility, high molecular weight, and denaturation issues within the solvent system (especially for collagen electrospun fibers), have limited their applications [151-154]. Combinations such as PLGA-collagen/gelatin [155,156], PCL-elastin [157], and PLA-silk [158], have reported that biocomposite fibrous scaffolds enhance cell adhesion and proliferation while providing suitable mechanical properties.

The flexibility of electrospinning has made it a promising approach for several biomedical applications such as dressings, tissue engineering scaffolds, and drug delivery devices. Table 5 shows examples of studies that have used electrospun fibers to study how stem 
cells interact with their fibrous ECM environment and how they respond to topographical cues (aligned or random fibers).

Table 5. Summary of electrospun constructs used to recreate the micro and nano spatial cues of the stem cell niche.

\begin{tabular}{ccc}
\hline Application & Polymer & Outcome \\
\hline Study adhesion and expansion of hHSCs & $\begin{array}{c}\text { Polyethersulfone (PES) aminated } \\
\text { using acrylic acid }\end{array}$ & $\begin{array}{c}\text { Non-woven PES nanofiber meshes of } \\
529 \pm 114 \text { nm in diameter. }\end{array}$ \\
\hline $\begin{array}{c}\text { Study the effects of fiber diameter on } \\
\text { NSC differentiation and proliferation }\end{array}$ & Laminin-coated PES mats & $\begin{array}{c}\text { Electrospun fiber meshes with } \\
\text { average diameters of 283 } \pm 45 \mathrm{~nm}, \\
749 \pm 153 \mathrm{~nm} \text {, and 1452 } \pm 312 \mathrm{~nm}\end{array}$ \\
\hline $\begin{array}{c}\text { Observe the sensibility of NSCs when } \\
\text { exposed to an aligned topography }\end{array}$ & $\begin{array}{c}\text { PCL fibrous mats coated with } \\
\text { polyornithine and laminin }\end{array}$ & $\begin{array}{c}\text { Aligned electrospun fibers with } \\
\text { average diameters of 251, 472, 923 nm, } \\
\text { and random fibers of 269, 481, } \\
\text { [1634 nm. }\end{array}$ \\
\hline $\begin{array}{c}\text { Study the influence of transplanting } \\
\text { MSCs and ESCs in re-epithelization }\end{array}$ & $\begin{array}{c}\text { Silk fibroin protein/gelatin } \\
\text { polymer solution }\end{array}$ & $\begin{array}{c}\text { Random or aligned uniform bead-less } \\
\text { fibers with diameters of 63.1 } \pm 2.7 \mathrm{~nm}\end{array}$ \\
\hline
\end{tabular}

Although most studies are based on the capacity of electrospun mats to resemble ECM nanofibrous nature, conventional electrospinning approaches have limitations regarding their capacity to recreate both nano and micro topographical components in one construct. As electrospinning excels at creating nanofibers up to $9 \mathrm{~nm}$ [163], but the process became unstable as fiber diameter increases above $10 \mu \mathrm{m}$ [164]. However, recent studies conducted by Ortega et al., have shown the potential of electrospinning to create microenvironments by combining conventional electrospinning with selective laser melting (SLM) [165] and $\mu S L A[166,167]$. These approaches are covered in detail further in this review.

\subsection{Other Fabrication Methods}

Increasing interest in replicating stem cell microenvironment has led to the use of novel techniques such as melt spinning or bioprinting, and to the refinement of processes to improve currently established techniques such as the use of two-photon polymerization (2PP). These techniques, although relevant to introduce stem cell niche-like features, will not be covered extensively in this review.

Melt spinning is an advanced manufacturing technique in which the polymer is extruded through a spinneret in a molten form, without the use of solvents. Two polymers can be coextruded to create a single filament with a designed cross-sectional arrangement. This technique is normally used in tissue engineering to generate macrofibers and to better control fiber alignment and pore size [168,169]. For example, melt spinning PLA fibers about 10-20 $\mu \mathrm{m}$ have been fabricated and polymerized with polypyrrole to study the effects of electrical stimulation on osteogenic differentiation of hASCs [170].

Bioprinting is the combination of 3D printing technologies (such as extrusion, inkjet, or laser-assisted) using cell and biocompatible supporting materials to create sections or entire artificial organs for regenerative medicine applications [171]. Current bioprinting methods mainly use extrusion based printing of cells, tissue spheroids, and biomaterials to achieve more complex and functional 3D structures [172]. A clear advantage of bio-printing is that it is possible to combine multiple bioinks (such as collagen, alginate, PEG, and PCL), cell types, and materials into complex 3D structures to mimic highly specific cell-matrix interactions within the stem cell microenvironment [173]. An example of this fabrication technique is the use of thermal inkjet with hMSCs suspended in PEGDMA co-printed with ceramic [174]. Other applications of adult stem cell 3D bioprinting are covered in detail by Ong et al. [175].

2-photon-polymerisation is a light-based manufacturing technology that uses short pulse length (femtosecond) lasers to polymerize photocurable resins via 2-photon absorption. This advanced fabrication technology can create 3D structures with a spatial 
resolution down to $100 \mathrm{~nm}$. It requires specific photopolymers that are usually modified ceramics, acrylic monomers, or polymerizable epoxides such as SU-8 [176]. The most common approach of using 2PP to recreate the stem cell microenvironment architecture is in combination with other techniques, such as creating precise molds for soft-lithography or hydrogel patterning. Nonetheless, several authors have reported its use more directly, by creating 3D devices that aim to replicate stem cell niches using photocurable biocompatible polymers [177] or hybrid organic-inorganic materials [178].

\subsection{Combining Micro and Nanofabrication Techniques}

As fabrication techniques become more available, the combination of one or more techniques has become feasible for research laboratories. The idea of overcoming certain limitations of a technique by integrating another fabrication method has proved successful for different applications. Table 6 summarizes attempts to introduce elements of the stem cell microenvironment by combining two or more manufacturing techniques. The low-cost setup and available polymers have made electrospinning a common technique that can be introduced in established or new constructs. In general, fabrication techniques are combined when a standalone process cannot provide either mechanical, chemical, physical, or spatial cues for the researchers to study stem cell fate.

Table 6. Summary of tissue engineered devices created to replicate the micro and nano spatial cues of the stem cell niche by combining two or more fabrication techniques.

\begin{tabular}{|c|c|c|c|}
\hline Application & Polymer & Outcome & Ref \\
\hline $\begin{array}{l}\text { Develop fibrous membranes with } \\
\text { controlled microenvironments to study } \\
\text { MSC behavior }\end{array}$ & $\begin{array}{l}\text { SLM metallic collectors used as } \\
\text { templates for PCL fibers }\end{array}$ & $\begin{array}{c}\text { Three different topographies were } \\
\text { tested with dimensions } 667,1038 \text {, and } \\
1168 \mu \mathrm{m} \text {. Average fiber diameter of } \\
1.8-2.2 \mu \mathrm{m}\end{array}$ & [165] \\
\hline $\begin{array}{c}\text { Study of osteogenesis of hMSCs using } \\
\text { sequential delivery of multiple } \\
\text { growth factors }\end{array}$ & $\begin{array}{l}\text { PCL/gelatin fibers incorporated } \\
\text { into PEG-diacrylate hydrogels }\end{array}$ & $\begin{array}{c}\text { PCL/gelatin microfibers of } \\
1.32 \pm 0.11 \mu \mathrm{m} \text { in diameter loaded } \\
\text { into square pattern arrays of } \\
1 \times 1 \mathrm{~mm}\end{array}$ & [179] \\
\hline $\begin{array}{l}\text { Design artificial limbal stem cell niches } \\
\text { using biodegradable electrospun rings } \\
\text { containing microfeatures }\end{array}$ & $\begin{array}{l}\text { Polyethylene glycol diacrylate } \\
\text { (PEGDA) collectors used with } \\
\text { PLGA 50:50 fibers }\end{array}$ & $\begin{array}{l}\text { Constructs of } 1.2 \mathrm{~cm} \text { diameter and } \\
0.36 \mathrm{~mm} \text { thickness containing } \\
\text { U-shaped micro pockets of } \\
150-300 \mu \mathrm{m} \text { diameter made of } \\
\text { microfibers of } \sim 3.5 \mu \mathrm{m} \text { in diameter. }\end{array}$ & [167] \\
\hline $\begin{array}{c}\text { Create patterned scaffolds to simulate the } \\
\text { anisotropic and multiscale architecture of } \\
\text { cardiac tissue, to promote cardiac } \\
\text { cell alignment }\end{array}$ & $\begin{array}{l}\text { Teflon-coated silicon wafer } \\
\text { patterned collector to use with a } \\
\text { blend of poly(glycerol sebacate) } \\
\text { (PGS) and PCL }\end{array}$ & $\begin{array}{l}\text { Fibrous constructs with an average } \\
\text { fiber diameter of } 1.2 \mu \text { and three } \\
\text { patterns tested: Two arrays of parallel } \\
\text { grooves of } 10 \mu \mathrm{m} \text {, and square shaped } \\
\text { features of } 100 \mu \mathrm{m} \text {. }\end{array}$ & [180] \\
\hline $\begin{array}{l}\text { Develop a new in vitro model in which to } \\
\text { study epithelial stem cell behavior }\end{array}$ & $\begin{array}{c}\text { Poly(3-hydroxybu- } \\
\text { tyrate-co-3-hydroxyvalerate } \\
\text { (PHBV) fibers patterned using a } \\
\text { PEGDA template }\end{array}$ & $\begin{array}{l}\text { Fibrous bilayer constructs with an } \\
\text { average fiber diameter of } 750 \mathrm{~nm} \text {. The } \\
\text { micropattern layer was made of } \\
\text { square or rectangular features of } \\
200-1000 \mu \mathrm{m} \text { in width and } \\
200-500 \mu \mathrm{m} \text { in depth. }\end{array}$ & [166] \\
\hline $\begin{array}{l}\text { Create a platform to mimic the cellular } \\
\text { microenvironment of hMSCs }\end{array}$ & $\begin{array}{l}\text { Oxygen plasma treated PDMS } \\
\text { microfluidic device with carboxyl } \\
\text { group modified PU fibers }\end{array}$ & $\begin{array}{l}\text { Microfluidic chip with randomly } \\
\text { orientated nanofibers of } \\
200-500 \mathrm{~nm} \text { diameter. }\end{array}$ & [181] \\
\hline $\begin{array}{l}\text { Study the use of a sandwich-type scaffold } \\
\text { to promote re-epithelialization }\end{array}$ & $\begin{array}{l}\text { Stainless steel collector coated } \\
\text { with plasma treated PCL } \\
\text { polymer fibers }\end{array}$ & $\begin{array}{l}\text { Random and aligned fibers with } \\
\text { microwells of } 200-280 \mu \mathrm{m} \text { in depth. } \\
\text { No fiber diameter was reported. }\end{array}$ & [182] \\
\hline $\begin{array}{l}\text { Develop a hybrid scaffold to study } \\
\text { chondrogenic differentiation of hMSCs } \\
\text { based on protein and gene expression }\end{array}$ & $\begin{array}{l}\text { Composite of a thermosensitive } \\
\text { PEG-PNIPAAm gel and } \\
\text { PCL fibers }\end{array}$ & $\begin{array}{l}\text { An electrospun scaffold of } \sim 11 \mu \mathrm{m} \\
\text { fiber diameter encapsulated in a } \\
\text { mold-less hydrogel. }\end{array}$ & [183] \\
\hline
\end{tabular}




\section{Future Perspective and Concluding Remarks}

The role of adult stem cells in the regenerative cycle of human tissues, their ability to differentiate into cells of the tissue from which they derive, and their relatively simple isolation protocols make them a promising tool to be used in regenerative medicine strategies. However, since their discovery, in vitro expansion of adult stem cells has remained a challenge due to the lack of native spatial and biochemical cues on traditional 2D culture platforms. Introducing complex physical cues within in vitro models can be a powerful approach to develop new routes for the study and control of stem cell behavior.

Soft-lithographic methods are easy, non-expensive techniques to recreate 2D surfaces with nano and micro features, however, they fail to provide a 3D network structure and have limited in vivo applications due to the chemical nature of the fabrication method. Complex fabrication techniques such as patterned hydrogels and microfluidic devices were initially developed using the basic principles of soft-lithography and therefore share certain techniques and challenges.

Hydrogels can introduce a 3D structure and can be patterned to create topographical cues that resemble stem cell niches. They can be fabricated from natural and synthetic materials and have been used for several in vivo applications due to their high biocompatibility, especially for natural materials. However, natural hydrogels such as alginate or collagen gels exhibit poor mechanical properties that usually require a post-processing covalent crosslinking step for most tissue engineering applications. This crosslinking step can compromise their biocompatibility due to the toxicity of the degradation products or reduced their bioactivity due to side-chain modifications [184-186]. Moreover, synthetic hydrogels need to be functionalized to further improve cell adhesion.

Microfluidic devices are mainly used as in vitro models rather than being a platform for tissue engineering applications. However, they excel at controlling and mimicking all components of the stem cell niche as a functional unit and they have become a gold standard for the development of in vitro studies of single and small populations of stem cells. The main limitation of microfluidic devices is their complex multi-step process, generally requiring different types of equipment as well as exhaustive control of multiple process parameters.

Electrospinning is used on the basis that it can replicate to a close degree the 3D fibrous environment of the stem cell niche [46,187-189]. Although it is mostly used for creating aligned or random fibrous environments, controlling fiber diameter and porosity can be achieved with simple modifications to the process or solution parameters. Its versatility to produce nano and microfibers from both natural and synthetic polymers has expanded the use of electrospinning in recent years. Moreover, electrospinning is an easy to perform and scalable process that has been used in several in vivo and in vitro tissue engineering applications, but on its own, it has limited applications for complex constructs to mimic the stem cell microenvironment.

Combining microfabrication techniques may lead to multifunctional complex tissue engineered constructs that could replicate several components of the stem cell niche and overcome individual challenges of each technique. Electrospinning seems to be the most versatile technique and can be successfully combined with other fabrication methodologies including soft lithography and micro-stereolithography. Although all the techniques reviewed here can also be further enhanced by introducing relevant biomolecules, microfluidic devices remain the most suitable in vitro model to test new biochemical cues and their effects on cell behavior as they allow for gradient concentration and controlled metabolite quantification.

All the methods described here introduce complexity to conventional 2D cell culture, and except for conventional electrospinning, their resolution depends directly on the photolithographic method used to create the master mold and the patterning technique. Introducing novel high-resolution techniques such as two-photon lithography to the fabrication of the master mold would significantly improve the spatial resolution of current lithographic constructs [190]. 
In summary, for achieving the successful incorporation of artificial microenvironments within future tissue engineering scaffolds for each particular tissue, the identification of the appropriate fabrication technique would be critical since it will ultimately define the potential complexity of the construct and therefore its functionality. Combining microfabrication techniques with innovative biofunctionalization strategies would certainly facilitate the creation of dynamic 3D environments where stem cells would be able to reside and differentiate on demand, leading to promising therapeutic approaches for tissue regeneration.

Author Contributions: Conceptualization, I.O.A. and D.H.R.-R.; writing-original draft preparation, I.O.A. and D.H.R.-R.; writing-review and editing, D.H.R.-R., I.O.A., S.M. and F.C.; visualization, D.H.R.-R.; supervision, I.O.A., S.M. and F.C.; project administration, I.O.A. and F.C.; funding acquisition, I.O.A. All authors have read and agreed to the published version of the manuscript.

Funding: The authors thank CONACyT for their financial support for David H. Ramos-Rodriguez.

Conflicts of Interest: The authors declare no conflict of interest.

\section{References}

1. Stice, S.L.; Boyd, N.L.; Dhara, S.K.; Gerwe, B.A.; Machacek, D.W.; Shin, S. Human embryonic stem cells: Challenges and opportunities. Reprod. Fertil. Dev. 2006, 18, 839-846. [CrossRef]

2. Lo, B.; Parham, L. Ethical Issues in Stem Cell Research. Endocr. Rev. 2009, 30, 204-213. [CrossRef]

3. Banks, J.M.; Harley, B.A.C.; Bailey, R.C. Tunable, Photoreactive Hydrogel System to Probe Synergies between Mechanical and Biomolecular Cues on Adipose-Derived Mesenchymal Stem Cell Differentiation. ACS Biomater. Sci. Eng. 2015, 1, 718-725. [CrossRef]

4. Alsberg, E.; Von Recum, H.A.; Mahoney, M.J. Environmental cues to guide stem cell fate decision for tissue engineering applications. Expert Opin. Biol. Ther. 2006, 6, 847-866. [CrossRef]

5. Zhang, Y.; Gordon, A.; Qian, W.; Chen, W. Engineering Nanoscale Stem Cell Niche: Direct Stem Cell Behavior at Cell-Matrix Interface. Adv. Health Mater. 2015, 4, 1900-1914. [CrossRef] [PubMed]

6. McNamara, L.E.; McMurray, R.J.; Biggs, M.J.P.; Kantawong, F.; Oreffo, R.O.C.; Dalby, M.J. Nanotopographical Control of Stem Cell Differentiation. J. Tissue Eng. 2010, 1, 120623. [CrossRef]

7. Morrison, S.J.; Kimble, J. Asymmetric and symmteric stem cell divisions in development cancer. Nature 2006, $441,1068-1074$. [CrossRef] [PubMed]

8. Li, L.; Xie, T. STEM CELL NICHE: Structure and Function. Annu. Rev. Cell Dev. Biol. 2005, 21, 605-631. [CrossRef]

9. Lutolf, M.P.; Blau, H.M. Artificial Stem Cell Niches. Adv. Mater. 2009, 21, 3255-3268. [CrossRef]

10. Loeffler, M.; Roeder, I. Tissue stem cells: Definition, plasticity, heterogeneity, self-organization and models-A conceptual approach. Cells Tissues Organs 2002, 171, 8-26. [CrossRef]

11. Schofield, R. The relationship between the spleen colony-forming cell and the haemopoietic stem cell. Blood Cells 1978, 4, 7-25.

12. Crittenden, S.L.; Eckmann, C.R.; Wang, L.; Bernstein, D.S.; Wickens, M.; Kimble, J. Regulation of the mitosis/meiosis decision in the Caenorhabditis elegans germline. Philos. Trans. R. Soc. B Biol. Sci. 2003, 358, 1359-1362. [CrossRef]

13. Lin, H.; Spradling, A.C. Germline Stem Cell Division and Egg Chamber Development in Transplanted Drosophila Germaria. Dev. Biol. 1993, 159, 140-152. [CrossRef]

14. Xie, T.; Spradling, A.C. A Niche Maintaining Germ Line Stem Cells in the Drosophila ovary. Science 2000, 290, 328-330. [CrossRef]

15. Jiang, J.; Papoutsakis, E.T. Stem-Cell Niche Based Comparative Analysis of Chemical and Nano-mechanical Material Properties Impacting Ex Vivo Expansion and Differentiation of Hematopoietic and Mesenchymal Stem Cells. Adv. Health Mater. 2012, 2, 25-42. [CrossRef]

16. Rezza, A.; Sennett, R.; Rendl, M. Adult Stem Cell Niches. Curr. Top. Dev. Biol. 2014, 107, 333-372. [CrossRef]

17. Jones, D.L.; Wagers, A.J. No place like home: Anatomy and function of the stem cell niche. Nat. Rev. Mol. Cell Biol. 2008, 9, 11-21. [CrossRef]

18. Conboy, I.M.; Conboy, M.J.; Wagers, A.J.; Girma, E.R.; Weissman, I.L.; Rando, T.A. Rejuvenation of aged progenitor cells by exposure to a young systemic environment. Nature 2005, 433, 760-764. [CrossRef]

19. Buom-Yong, R.; Orwig, K.E.; Oatley, J.M.; Avarbock, M.R.; Brinster, R.L. Effects of Aging and Niche Microenvironment on Spermatogonial Stem Cell Self Renewal. Stem Cells 2006, 24, 1505-1511. [CrossRef]

20. Greco, V.; Guo, S. Compartmentalized organization: A common and required feature of stem cell niches? Development 2010, 137, 1586-1594. [CrossRef]

21. Lavker, R.M.; Sun, T.-T. Epidermal stem cells: Properties, markers, and location. Proc. Natl. Acad. Sci. USA 2000, 97, 13473-13475. [CrossRef]

22. Pincelli, C.; Marconi, A. Keratinocyte stem cells: Friends and foes. J. Cell. Physiol. 2010, 225, 310-315. [CrossRef]

23. Lawlor, K.T.; Kaur, P. Dermal Contributions to Human Interfollicular Epidermal Architecture and Self-Renewal. Int. J. Mol. Sci. 2015, 16, 28098-28107. [CrossRef] 
24. Webb, A.; Li, A.; Kaur, P. Location and phenotype of human adult keratinocyte stem cells of the skin. Differentiation 2004, 72, 387-395. [CrossRef]

25. Morrison, S.J.; Scadden, D.T. The bone marrow niche for haematopoietic stem cells. Nature 2014, 505, 327-334. [CrossRef]

26. Ehninger, A.; Trumpp, A. The bone marrow stem cell niche grows up: Mesenchymal stem cells and macrophages move in. J. Exp. Med. 2011, 208, 421-428. [CrossRef]

27. Santos, A.J.; Lo, Y.-H.; Mah, A.T.; Kuo, C.J. The Intestinal Stem Cell Niche: Homeostasis and Adaptations. Trends Cell Biol. 2018, 28, 1062-1078. [CrossRef]

28. Leri, A.; Rota, M.; Hosoda, T.; Goichberg, P.; Anversa, P. Cardiac stem cell niches. Stem Cell Res. 2014, 13, 631-646. [CrossRef]

29. Jayasuriya, C.T.; Chen, Y.; Liu, W.; Chen, Q. The influence of tissue microenvironment on stem cell-based cartilage repair. Ann. N. Y. Acad. Sci. 2016, 1383, 21-33. [CrossRef]

30. Shortt, A.J.; Secker, G.A.; Munro, P.M.; Khaw, P.T.; Tuft, S.J.; Daniels, J.T. Characterization of the Limbal Epithelial Stem Cell Niche: Novel Imaging Techniques Permit In Vivo Observation and Targeted Biopsy of Limbal Epithelial Stem Cells. Stem Cells 2007, 25, 1402-1409. [CrossRef]

31. Cheng, L.-C.; Pastrana, E.; Tavazoie, M.; Doetsch, F. miR-124 regulates adult neurogenesis in the SVZ stem cell niche. Nat. Neurosci. 2009, 12, 399-408. [CrossRef]

32. Doetsch, F. A niche for adult neural stem cells. Curr. Opin. Genet. Dev. 2003, 13, 543-550. [CrossRef]

33. Parent, J.M. Adult neurogenesis in the intact and epileptic dentate gyrus. Prog. Brain Res. 2007, 163, 529-817. [CrossRef]

34. Volckaert, T.; De Langhe, S. Lung epithelial stem cells and their niches: Fgf10 takes center stage. Fibrogenes. Tissue Repair 2014, 7, 8. [CrossRef]

35. Borthwick, D.W.; Shahbazian, M.; Krantz, Q.T.; Dorin, J.R.; Randell, S.H. Evidence for Stem-Cell Niches in the Tracheal Epithelium. Am. J. Respir. Cell Mol. Biol. 2001, 24, 662-670. [CrossRef]

36. Graziano, A.; d'Aquino, R.; Laino, G.; Papaccio, G. Dental pulp stem cells: A promising tool for bone regeneration. Stem Cell Rev. 2008, 4, 21-26. [CrossRef]

37. Mitsiadis, T.; Feki, A.; Papaccio, G.; Catón, J. Dental Pulp Stem Cells, Niches, and Notch Signaling in Tooth Injury. Adv. Dent. Res. 2011, 23, 275-279. [CrossRef]

38. Crane, G.M.; Jeffery, E.; Morrison, S.J. Adult haematopoietic stem cell niches. Nat. Rev. Immunol. 2017, 17, 573-590. [CrossRef] [PubMed]

39. Moore, K.A. Stem Cells and Their Niches. Science 2006, 311, 1880-1885. [CrossRef]

40. Li, W.; Hayashida, Y.; Chen, Y.-T.; Tseng, S.C.G. Niche regulation of corneal epithelial stem cells at the limbus. Cell Res. 2007, 17, 26-36. [CrossRef]

41. Riether, C.; Schurch, C.; Ochsenbein, A.F. Regulation of hematopoietic and leukemic stem cells by the immune system. Cell Death Differ. 2015, 22, 187-198. [CrossRef] [PubMed]

42. Li, L.; Clevers, H. Coexistence of Quiescent and Active Adult Stem Cells in Mammals. Science 2010, 327, 542-545. [CrossRef] [PubMed]

43. Chacón-Martínez, C.A.; Koester, J.; Wickström, S.A. Signaling in the stem cell niche: Regulating cell fate, function and plasticity. Development 2018, 145, dev165399. [CrossRef]

44. Boyle, M.; Wong, C.; Rocha, M.; Jones, D.L. Decline in Self-Renewal Factors Contributes to Aging of the Stem Cell Niche in the Drosophila Testis. Cell Stem Cell 2007, 1, 470-478. [CrossRef]

45. Hsu, H.-J.; Drummond-Barbosa, D. Insulin signals control the competence of the Drosophila female germline stem cell niche to respond to Notch ligands. Dev. Biol. 2011, 350, 290-300. [CrossRef]

46. Dellatore, S.M.; Garcia, A.S.; Miller, W.M. Mimicking stem cell niches to increase stem cell expansion. Curr. Opin. Biotechnol. 2008, 19, 534-540. [CrossRef]

47. Garcion, E.; Halilagic, A.; Faissner, A.; Ffrench-Constant, C. Generation of an environmental niche for neural stem cell development bythe extracellular matrix molecule tenascin C. Development 2004, 131, 3423-3432. [CrossRef]

48. Hynes, R.O. Extracellular matrix: Not just pretty fibrils. Science 2009, 326, 1216-1219. [CrossRef]

49. Abdelmoneim, D.; Alhamdani, G.M.; Paterson, T.E.; Romero, M.E.S.; Monteiro, B.J.C.; Hatton, P.V.; Asencio, I.O. Bioactive and Topographically-Modified Electrospun Membranes for the Creation of New Bone Regeneration Models. Process 2020, 8, 1341. [CrossRef]

50. Scadden, D.T. The stem-cell niche as an entity of action. Nat. Cell Biol. 2006, 441, 1075-1079. [CrossRef]

51. Ruoslahti, E.; Pierschbacher, M.D. Arg-Gly-Asp: A versatile cell recognition signal. Cell 1986, 44, 517-518. [CrossRef]

52. Smith-Berdan, S.; Nguyen, A.; Hassanein, D.; Zimmer, M.; Ugarte, F.; Ciriza, J.; Li, D.; García-Ojeda, M.E.; Hinck, L.; Forsberg, E.C. Robo4 Cooperates with Cxcr4 to Specify Hematopoietic Stem Cell Localization to Bone Marrow Niches. Cell Stem Cell 2011, 8, 72-83. [CrossRef] [PubMed]

53. Avigdor, A.; Goichberg, P.; Shivtiel, S.; Dar, A.; Peled, A.; Samira, S.; Kollet, O.; Hershkoviz, R.; Alon, R.; Hardan, I.; et al. CD44 and hyaluronic acid cooperate with SDF-1 in the traf cking of human CD34+ stem/progenitor cells to bone marrow. Blood 2004, 103, 2981-2989. [CrossRef] [PubMed]

54. Gattazzo, F.; Urciuolo, A.; Bonaldo, P. Extracellular matrix: A dynamic microenvironment for stem cell niche. Biochim. Acta 2014, 1840, 2506-2519. [CrossRef] 
55. Ellis, S.J.; Tanentzapf, G. Integrin-mediated adhesion and stem-cell-niche interactions. Cell Tissue Res. 2009, 339, 121-130. [CrossRef]

56. Sharma, M.B.; Limaye, L.S.; Kale, V.P. Mimicking the functional hematopoietic stem cell niche in vitro: Recapitulation of marrow physiology by hydrogel-based three-dimensional cultures of mesenchymal stromal cells. Haematologica 2011, 97, 651-660. [CrossRef]

57. Kobel, S.; Lutolf, M. High-throughput methods to define complex stem cell niches. Biotechniques 2010, 48, ix-xxii. [CrossRef]

58. Weiss, P.; Garber, B. Shape and Movement of Mesenchyme Cells as Functions of the Physical Structure of the Medium: Contributions to a Quantitative Morphology. Proc. Natl. Acad. Sci. USA 1952, 38, 264-280. [CrossRef]

59. Curtis, A.S.; Varde, M. Control of cell behavior: Topological factors. J. Natl. Cancer Inst. 1964, 33, 15-26.

60. Yim, E.K.; Darling, E.M.; Kulangara, K.; Guilak, F.; Leong, K.W. Nanotopography-induced changes in focal adhesions, cytoskeletal organization, and mechanical properties of human mesenchymal stem cells. Biomaterials 2010, 31, 1299-1306. [CrossRef]

61. Murphy, W.L.; McDevitt, T.C.; Engler, A.J. Materials as stem cell regulators. Nat. Mater. 2014, 13, 547-557. [CrossRef]

62. Farrukh, A.; Zhao, S.; Del Campo, A. Microenvironments Designed to Support Growth and Function of Neuronal Cells. Front. Mater. 2018, 5, 1-22. [CrossRef]

63. Tran, K.T.; Nguyen, T.D. Lithography-based methods to manufacture biomaterials at small scales. J. Sci. Adv. Mater. Devices 2017, 2, 1-14. [CrossRef]

64. Khademhosseini, A.; Langer, R.; Borenstein, J.; Vacanti, J.P. Microscale technologies for tissue engineering and biology. Proc. Natl. Acad. Sci. USA 2006, 103, 2480-2487. [CrossRef]

65. Qin, D.; Xia, Y.; Whitesides, G.M. Soft lithography for micro- and nanoscale patterning. Nat. Protoc. 2010, 5, 491-502. [CrossRef]

66. Acikgoz, C.; Hempenius, M.A.; Huskens, J.; Vancso, G.J. Polymers in conventional and alternative lithography for the fabrication of nanostructures. Eur. Polym. J. 2011, 47, 2033-2052. [CrossRef]

67. Tanaka, N.; Ota, H.; Fukumori, K.; Miyake, J.; Yamato, M.; Okano, T. Micro-patterned cell-sheets fabricated with stamping-forcecontrolled micro-contact printing. Biomaterials 2014, 35, 9802-9810. [CrossRef] [PubMed]

68. Ungrin, M.D.; Joshi, C.; Nica, A.; Bauwens, C.; Zandstra, P.W. Reproducible, Ultra High-Throughput Formation of Multicellular Organization from Single Cell Suspension-Derived Human Embryonic Stem Cell Aggregates. PLoS ONE 2008, 3, e1565. [CrossRef]

69. Müller, E.; Pompe, T.; Freudenberg, U.; Werner, C. Solvent-Assisted Micromolding of Biohybrid Hydrogels to Maintain Human Hematopoietic Stem and Progenitor Cells Ex Vivo. Adv. Mater. 2017, 29, 1703489. [CrossRef] [PubMed]

70. Ye, F.; Jiang, J.; Chang, H.; Xie, L.; Deng, J.; Ma, Z.; Yuan, W. Improved single-cell culture achieved using micromolding in capillaries technology coupled with poly (HEMA). Biomicrofluidics 2015, 9, 044106. [CrossRef] [PubMed]

71. Gadegaard, N.; Dalby, M.J.; Martines, E.; Seunarine, K.; Riehle, M.O.; Curtis, A.S.; Wilkinson, C.D. Nano Patterned Surfaces for Biomaterial Applications. Adv. Sci. Technol. 2006, 53, 107-115. [CrossRef]

72. McMurray, R.J.; Gadegaard, N.; Tsimbouri, P.M.; Burgess, K.V.; McNamara, L.E.; Tare, R.S.; Murawski, K.; Kingham, E.; Oreffo, R.O.C.; Dalby, M.J. Nanoscale surfaces for the long-term maintenance of mesenchymal stem cell phenotype and multipotency. Nat. Mater. 2011, 10, 637-644. [CrossRef] [PubMed]

73. Donnelly, H.; Salmeron-Sanchez, M.; Dalby, M.J. Designing stem cell niches for differentiation and self-renewal. J. R. Soc. Interface 2018, 15, 20180388. [CrossRef] [PubMed]

74. Dalby, M.J.; Gadegaard, N.; Tare, R.; Andar, A.; Riehle, M.O.; Herzyk, P.; Wilkinson, C.D.W.; Oreffo, R.O.C. The control of human mesenchymal cell differentiation using nanoscale symmetry and disorder. Nat. Mater. 2007, 6, 997-1003. [CrossRef]

75. Sahin, O.; AshokKumar, M.; Ajayan, P.M. Micro- and nanopatterning of biomaterial surfaces. In Fundamental Biomaterials: Metals; Elsevier: Amsterdam, The Netherlands, 2018; pp. 67-78.

76. Gates, B.D.; Xu, Q.; Stewart, M.; Ryan, D.; Willson, C.G.; Whitesides, G.M. New Approaches to Nanofabrication: Molding, Printing, and Other Techniques. Chem. Rev. 2005, 105, 1171-1196. [CrossRef]

77. Schmid, H.; Michel, B. Siloxane Polymers for High-Resolution, High-Accuracy Soft Lithography. Macromolecules 2000, 33, 3042-3049. [CrossRef]

78. Cordey, M.; Limacher, M.; Kobel, S.; Taylor, V.; Lutolf, M.P. Enhancing the Reliability and Throughput of Neurosphere Culture on Hydrogel Microwell Arrays. Stem Cells 2008, 26, 2586-2594. [CrossRef]

79. Boldrin, L.; Elvassore, N.; Malerba, A.; Flaibani, M.; Cimetta, E.; Piccoli, M.; Baroni, M.D.; Gazzola, M.V.; Messina, C.; Gamba, P.; et al. Satellite Cells Delivered by Micro-Patterned Scaffolds: A New Strategy for Cell Transplantation in Muscle Diseases. Tissue Eng. 2007, 13, 253-262. [CrossRef]

80. McUsic, A.C.; Lamba, D.A.; Reh, T.A. Guiding the morphogenesis of dissociated newborn mouse retinal cells and hES cell-derived retinal cells by soft lithography-patterned microchannel PLGA scaffolds. Biomaterials 2012, 33, 1396-1405. [CrossRef]

81. Qian, Z.; Ross, D.; Jia, W.; Xing, Q.; Zhao, F. Bioactive polydimethylsiloxane surface for optimal human mesenchymal stem cell sheet culture. Bioact. Mater. 2018, 3, 167-173. [CrossRef]

82. Ghaemi, S.R.; Harding, F.J.; Delalat, B.; Gronthos, S.; Voelcker, N.H. Exploring the mesenchymal stem cell niche using high throughput screening. Biomaterials 2013, 34, 7601-7615. [CrossRef] [PubMed]

83. Green, A.M.; Jansen, J.A.; Van Der Waerden, J.P.; Von Recum, A.F. Fibroblast response to microtextured silicone surfaces: Texture orientation into or out of the surface. J. Biomed. Mater. Res. 1994, 28, 647-653. [CrossRef] [PubMed]

84. Meyle, J.; Gültig, K.; Nisch, W. Variation in contact guidance by human cells on a microstructured surface. J. Biomed. Mater. Res. 1995, 29, 81-88. [CrossRef] 
85. Chen, S.; Lewallen, M.; Xie, T. Adhesion in the stem cell niche: Biological roles and regulation. Development 2012, 140, $255-265$. [CrossRef] [PubMed]

86. Hwang, N.S.; Varghese, S.; Elisseeff, J. Controlled differentiation of stem cells. Adv. Drug Deliv. Rev. 2008, 60, 199-214. [CrossRef]

87. Wood, A. Contact guidance on microfabricated substrata: The response of teleost fin mesenchyme cells to repeating topographical patterns. J. Cell Sci. 1988, 90, 667-681. [PubMed]

88. Zhang, W.; Choi, D.S.; Nguyen, Y.H.; Chang, J.; Qin, L. Studying Cancer Stem Cell Dynamics on PDMS Surfaces for Microfluidics Device Design. Sci. Rep. 2013, 3, srep02332. [CrossRef]

89. Watari, S.; Hayashi, K.; Wood, J.A.; Russell, P.; Nealey, P.F.; Murphy, C.J.; Genetos, D.C. Modulation of osteogenic differentiation in hMSCs cells by submicron topographically-patterned ridges and grooves. Biomaterials 2012, 33, 128-136. [CrossRef]

90. Clement, A.L.; Moutinho, T.J.; Pins, G.D. Micropatterned dermal-epidermal regeneration matrices create functional niches that enhance epidermal morphogenesis. Acta Biomater. 2013, 9, 9474-9484. [CrossRef]

91. Magin, C.M.; Neale, D.B.; Drinker, M.C.; Willenberg, B.J.; Reddy, S.T.; La Perle, K.M.; Schultz, G.S.; Brennan, A.B. Evaluation of a bilayered, micropatterned hydrogel dressing for full-thickness wound healing. Exp. Biol. Med. 2016, 241, 986-995. [CrossRef]

92. You, M.-H.; Kwak, M.K.; Kim, D.-H.; Kim, K.; Levchenko, A.; Kim, D.-Y.; Suh, K.-Y. Synergistically Enhanced Osteogenic Differentiation of Human Mesenchymal Stem Cells by Culture on Nanostructured Surfaces with Induction Media. Biomacromolecules 2010, 11, 1856-1862. [CrossRef] [PubMed]

93. Bush, K.A.; Pins, G.D. Development of Microfabricated Dermal Epidermal Regenerative Matrices to Evaluate the Role of Cellular Microenvironments on Epidermal Morphogenesis. Tissue Eng. Part A 2012, 18, 2343-2353. [CrossRef] [PubMed]

94. Sayin, E.; Baran, E.T.; Hasirci, V. Osteogenic differentiation of adipose derived stem cells on high and low aspect ratio micropatterns. J. Biomater. Sci. Polym. Ed. 2015, 26, 1402-1424. [CrossRef] [PubMed]

95. Yu, J.Z.; Korkmaz, E.; Berg, M.I.; LeDuc, P.R.; Ozdoganlar, O.B. Biomimetic scaffolds with three-dimensional undulated microtopographies. Biomaterials 2017, 128, 109-120. [CrossRef] [PubMed]

96. Viswanathan, P.; Guvendiren, M.; Chua, W.; Telerman, S.B.; Liakath-Ali, K.; Burdick, J.A.; Watt, F.M. Mimicking the topography of the epidermal-dermal interface with elastomer substrates. Integr. Biol. 2015, 8, 21-29. [CrossRef] [PubMed]

97. Braber, E.T.D.; De Ruijter, J.E.; Smits, H.T.J.; Ginsel, L.A.; Von Recum, A.F.; Jansen, J.A. Effect of parallel surface microgrooves and surface energy on cell growth. J. Biomed. Mater. Res. 1995, 29, 511-518. [CrossRef] [PubMed]

98. Khadpekar, A.J.; Khan, M.; Sose, A.; Majumder, A. Low Cost and Lithography-free Stamp fabrication for Microcontact Printing. Sci. Rep. 2019, 9, 1024. [CrossRef] [PubMed]

99. Kim, Y.S.; Lee, H.H.; Hammond, P.T. High density nanostructure transfer in soft molding using polyurethane acrylate molds and polyelectrolyte multilayers. Nanotechnology 2003, 14, 1140-1144. [CrossRef]

100. Nagamine, K.; Hirata, T.; Okamoto, K.; Abe, Y.; Kaji, H.; Nishizawa, M. Portable Micropatterns of Neuronal Cells Supported by Thin Hydrogel Films. ACS Biomater. Sci. Eng. 2015, 1, 329-334. [CrossRef]

101. Chai, Q.; Jiao, Y.; Yu, X. Hydrogels for Biomedical Applications: Their Characteristics and the Mechanisms behind Them. Gels 2017, 3, 6. [CrossRef]

102. Ahmed, E.M. Hydrogel: Preparation, characterization, and applications: A review. J. Adv. Res. 2015, 6, 105-121. [CrossRef]

103. Cuchiara, M.L.; Coşkun, S.; Banda, O.A.; Horter, K.L.; Hirschi, K.K.; West, J.L. Bioactive poly(ethylene glycol) hydrogels to recapitulate the HSC niche and facilitate HSC expansion in culture. Biotechnol. Bioeng. 2015, 113, 870-881. [CrossRef] [PubMed]

104. Beckstead, B.L.; Santosa, D.M.; Giachelli, C.M. Mimicking cell-cell interactions at the biomaterial-cell interface for control of stem cell differentiation. J. Biomed. Mater. Res. Part A 2006, 79, 94-103. [CrossRef]

105. Paul, A.; Stührenberg, M.; Chen, S.; Rhee, D.; Lee, W.-K.; Odom, T.W.; Heilshorn, S.C.; Enejder, A. Micro- and nano-patterned elastin-like polypeptide hydrogels for stem cell culture. Soft Matter 2017, 13, 5665-5675. [CrossRef]

106. Egawa, E.Y.; Kato, K.; Hiraoka, M.; Nakaji-Hirabayashi, T.; Iwata, H. Enhanced proliferation of neural stem cells in a collagen hydrogel incorporating engineered epidermal growth factor. Biomaterials 2011, 32, 4737-4743. [CrossRef]

107. Khetan, S.; Guvendiren, M.; Legant, W.R.; Cohen, D.M.; Chen, C.S.; Burdick, J.A. Degradation-mediated cellular traction directs stem cell fate in covalently crosslinked three-dimensional hydrogels. Nat. Mater. 2013, 12, 458-465. [CrossRef] [PubMed]

108. Shin, H. Fabrication methods of an engineered microenvironment for analysis of cell-biomaterial interactions. Biomaterials 2007, 28, 126-133. [CrossRef]

109. Pelham, R.J.; Wang, Y.-L. Cell locomotion and focal adhesions are regulated by substrate flexibility. Proc. Natl. Acad. Sci. USA 1997, 94, 13661-13665. [CrossRef]

110. Antoine, E.E.; Vlachos, P.P.; Rylander, M.N. Review of Collagen I Hydrogels for Bioengineered Tissue Microenvironments: Characterization of Mechanics, Structure, and Transport. Tissue Eng. Part B Rev. 2014, 20, 683-696. [CrossRef]

111. Antoine, E.E.; Vlachos, P.P.; Rylander, M.N. Tunable Collagen I Hydrogels for Engineered Physiological Tissue MicroEnvironments. PLoS ONE 2015, 10, e0122500. [CrossRef] [PubMed]

112. Lee, K.Y.; Mooney, D.J. Hydrogels for Tissue Engineering. Chem. Rev. 2001, 101, 1869-1880. [CrossRef] [PubMed]

113. Zhu, J. Bioactive modification of poly(ethylene glycol) hydrogels for tissue engineering. Biomaterials 2010, 31, 4639-4656. [CrossRef] [PubMed]

114. Muth, C.A.; Steinl, C.B.; Klein, G.; Lee-Thedieck, C. Regulation of Hematopoietic Stem Cell Behavior by the Nanostructured Presentation of Extracellular Matrix Components. PLoS ONE 2013, 8, e54778. [CrossRef] 
115. Kratzer, D.; Ludwig-Husemann, A.; Junges, K.; Geckle, U.; Lee-Thedieck, C. Nanostructured Bifunctional Hydrogels as Potential Instructing Platform for Hematopoietic Stem Cell Differentiation. Front. Mater. 2019, 5, 1-16. [CrossRef]

116. Cuchiara, M.P.; Allen, A.C.; Chen, T.M.; Miller, J.S.; West, J.L. Multilayer microfluidic PEGDA hydrogels. Biomaterials 2010, 31, 5491-5497. [CrossRef]

117. Levis, H.J.; Massie, I.; Dziasko, M.A.; Kaasi, A.; Daniels, J.T. Rapid tissue engineering of biomimetic human corneal limbal crypts with 3D niche architecture. Biomaterials 2013, 34, 8860-8868. [CrossRef]

118. Massie, I.; Kureshi, A.K.; Schrader, S.; Shortt, A.J.; Daniels, J.T. Optimization of optical and mechanical properties of real architecture for 3-dimensional tissue equivalents: Towards treatment of limbal epithelial stem cell deficiency. Acta Biomater. 2015, 24, 241-250. [CrossRef]

119. Kim, D.-H.; Smith, R.R.; Kim, P.; Ahn, E.H.; Kim, H.-N.; Marbán, E.; Suh, K.-Y.; Levchenko, A. Nanopatterned cardiac cell patches promote stem cell niche formation and myocardial regeneration. Integr. Biol. 2012, 4, 1019-1033. [CrossRef]

120. Yang, J.; Li, Y.; Liu, Y.; Li, D.; Zhang, L.; Wang, Q.; Xiao, Y.; Zhang, X. Influence of hydrogel network microstructures on mesenchymal stem cell chondrogenesis in vitro and in vivo. Acta Biomater. 2019, 91, 159-172. [CrossRef]

121. Cuchiara, M.L.; Horter, K.L.; Banda, O.A.; West, J.L. Covalent immobilization of stem cell factor and stromal derived factor $1 \alpha$ for in vitro culture of hematopoietic progenitor cells. Acta Biomater. 2013, 9, 9258-9269. [CrossRef] [PubMed]

122. Jeon, O.; Alsberg, E. Regulation of Stem Cell Fate in a Three-Dimensional Micropatterned Dual-Crosslinked Hydrogel System. Adv. Funct. Mater. 2013, 23, 4765-4775. [CrossRef]

123. Vignesh, S.; Gopalakrishnan, A.; Poorna, M.R.; Nair, S.V.; Jayakumar, R.; Mony, U.; Poorna, M. Fabrication of micropatterned alginate-gelatin and k-carrageenan hydrogels of defined shapes using simple wax mould method as a platform for stem cell/induced Pluripotent Stem Cells (iPSC) culture. Int. J. Biol. Macromol. 2018, 112, 737-744. [CrossRef] [PubMed]

124. Kang, D.H.; Kim, S.M.; Lee, B.; Yoon, H.; Suh, K.-Y. Stimuli-responsive hydrogel patterns for smart microfluidics and microarrays. Analyst 2013, 138, 6230-6242. [CrossRef] [PubMed]

125. Tanaka, M.; Nakahata, M.; Linke, P.; Kaufmann, S. Stimuli-responsive hydrogels as a model of the dynamic cellular microenvironment. Polym. J. 2020, 52, 861-870. [CrossRef]

126. Huang, Y.; Agrawal, B.; Sun, D.; Kuo, J.S.; Williams, J.C. Microfluidics-based devices: New tools for studying cancer and cancer stem cell migration. Biomicrofluidics 2011, 5, 013412. [CrossRef] [PubMed]

127. Zhang, J.; Wei, X.; Zeng, R.; Xu, F.; Li, X. Stem cell culture and differentiation in microfluidic devices toward organ-on-a-chip. Futur. Sci. OA 2017, 3, FSO187. [CrossRef]

128. Lee, S.; Jin, S.-P.; Kim, Y.K.; Sung, G.Y.; Chung, J.H.; Sung, J.H. Construction of 3D multicellular microfluidic chip for an in vitro skin model. Biomed. Microdevices 2017, 19, 22. [CrossRef] [PubMed]

129. Krishna, L.; Dhamodaran, K.; Jayadev, C.; Chatterjee, K.; Shetty, R.; Khora, S.S.; Das, D. Nanostructured scaffold as a determinant of stem cell fate. Stem Cell Res. Ther. 2016, 7, 188. [CrossRef]

130. Coluccio, M.L.; Perozziello, G.; Malara, N.; Parrotta, E.; Zhang, P.; Gentile, F.; Limongi, T.; Raj, P.M.; Cuda, G.; Candeloro, P.; et al. Microfluidic platforms for cell cultures and investigations. Microelectron. Eng. 2019, 208, 14-28. [CrossRef]

131. Zhang, Q.; Austin, R.H. Applications of Microfluidics in Stem Cell Biology. BioNanoScience 2012, 2, 277-286. [CrossRef]

132. Choi, N.W.; Cabodi, M.; Held, B.; Gleghorn, J.P.; Bonassar, L.J.; Stroock, A.D. Microfluidic scaffolds for tissue engineering. Nat. Mater. 2007, 6, 908-915. [CrossRef]

133. Peeni, B.A.; Lee, M.L.; Hawkins, A.R.; Woolley, A.T. Sacrificial Layer Microfluidic Device Fabrication Methods Bridget. Electrophoresis 2006, 27, 4888-4895. [CrossRef]

134. Allazetta, S.; Lutolf, M.P. Stem cell niche engineering through droplet microfluidics. Curr. Opin. Biotechnol. $2015,35,86-93$. [CrossRef] [PubMed]

135. Golden, A.P.; Tien, J. Fabrication of microfluidic hydrogels using molded gelatin as a sacrificial element. Lab Chip 2007, 7, 720-725. [CrossRef]

136. Kim, J.A.; Hong, S.; Rhee, W.J. Microfluidic three-dimensional cell culture of stem cells for high-throughput analysis. World J. Stem Cells 2019, 11, 803-816. [CrossRef]

137. Chin, V.I.; Taupin, P.; Sanga, S.; Scheel, J.; Gage, F.H.; Bhatia, S.N. Microfabricated platform for studying stem cell fates. Biotechnol. Bioeng. 2004, 88, 399-415. [CrossRef] [PubMed]

138. Shin, Y.; Yang, K.; Han, S.; Park, H.-J.; Heo, Y.S.; Cho, S.-W.; Chung, S. Reconstituting Vascular Microenvironment of Neural Stem Cell Niche in Three-Dimensional Extracellular Matrix. Adv. Health Mater. 2014, 3, 1457-1464. [CrossRef] [PubMed]

139. Allazetta, S.; Hausherr, T.C.; Lutolf, M.P. Microfluidic Synthesis of Cell-Type-Specific Artificial Extracellular Matrix Hydrogels. Biomacromolecules 2013, 14, 1122-1131. [CrossRef]

140. Tumarkin, E.; Tzadu, L.; Csaszar, E.; Seo, M.; Zhang, H.; Lee, A.; Peerani, R.; Purpura, K.; Zandstra, P.W.; Kumacheva, E. High-throughput combinatorial cell co-culture using microfluidics. Integr. Biol. 2011, 3, 653-662. [CrossRef] [PubMed]

141. Brandenberg, N.; Lutolf, M.P. In Situ Patterning of Microfluidic Networks in 3D Cell-Laden Hydrogels. Adv. Mater. 2016, 28, 7450-7456. [CrossRef]

142. Hsiao, A.Y.; Torisawa, Y.-S.; Tung, Y.-C.; Sud, S.; Taichman, R.S.; Pienta, K.J.; Takayama, S. Microfluidic system for formation of PC-3 prostate cancer co-culture spheroids. Biomaterials 2009, 30, 3020-3027. [CrossRef]

143. Bhardwaj, N.; Kundu, S.C. Electrospinning: A fascinating fiber fabrication technique. Biotechnol. Adv. 2010, $28,325-347$. [CrossRef] [PubMed] 
144. Hu, X.; Liu, S.; Zhou, G.; Huang, Y.; Xie, Z.; Jing, X. Electrospinning of polymeric nanofibers for drug delivery applications. J. Control. Release 2014, 185, 12-21. [CrossRef]

145. Sill, T.J.; Von Recum, H.A. Electrospinning: Applications in drug delivery and tissue engineering. Biomaterials 2008, 29, 1989-2006. [CrossRef] [PubMed]

146. Dias, J.; Granja, P.; Bártolo, P. Advances in electrospun skin substitutes. Prog. Mater. Sci. 2016, 84, 314-334. [CrossRef]

147. Blackwood, K.A.; Mckean, R.; Canton, I.; Freeman, C.O.; Franklin, K.L.; Cole, D.; Brook, I.; Farthing, P.; Rimmer, S.; Haycock, J.W.; et al. Development of biodegradable electrospun scaffolds for dermal replacement. Biomaterials 2008, 29, 3091-3104. [CrossRef] [PubMed]

148. Repanas, A.; Andriopoulou, S.; Glasmacher, B. The significance of electrospinning as a method to create fibrous scaffolds for biomedical engineering and drug delivery applications. J. Drug Deliv. Sci. Technol. 2016, 31, 137-146. [CrossRef]

149. Li, M.; Mondrinos, M.J.; Gandhi, M.R.; Ko, F.K.; Weiss, A.S.; Lelkes, P.I. Electrospun protein fibers as matrices for tissue engineering. Biomaterials 2005, 26, 5999-6008. [CrossRef] [PubMed]

150. Zhang, X.; Reagan, M.R.; Kaplan, D.L. Electrospun silk biomaterial scaffolds for regenerative medicine. Adv. Drug Deliv. Rev. 2009, 61, 988-1006. [CrossRef]

151. Liu, X.; Baldursdottir, S.G.; Aho, J.; Qu, H.; Christensen, L.P.; Rantanen, J.; Yang, M. Electrospinnability of Poly Lactic-co-glycolic Acid (PLGA): The Role of Solvent Type and Solvent Composition. Pharm. Res. 2017, 34, 738-749. [CrossRef]

152. Zha, Z.; Teng, W.; Markle, V.; Dai, Z.; Wu, X. Fabrication of gelatin nanofibrous scaffolds using ethanol/phosphate buffer saline as a benign solvent. Biopolymers 2012, 97, 1026-1036. [CrossRef] [PubMed]

153. Song, J.-H.; Kim, H.-E.; Kim, H.-W. Production of electrospun gelatin nanofiber by water-based co-solvent approach. J. Mater. Sci. Mater. Med. 2008, 19, 95-102. [CrossRef] [PubMed]

154. Jiang, Q.; Reddy, N.; Zhang, S.; Roscioli, N.; Yang, Y. Water-stable electrospun collagen fibers from a non-toxic solvent and crosslinking system. J. Biomed. Mater. Res. Part A 2012, 101, 1237-1247. [CrossRef]

155. Liu, S.-J.; Kau, Y.-C.; Chou, C.-Y.; Chen, J.-K.; Wu, R.-C.; Yeh, W.-L. Electrospun PLGA/collagen nanofibrous membrane as early-stage wound dressing. J. Membr. Sci. 2010, 355, 53-59. [CrossRef]

156. Meng, Z.; Wang, Y.; Ma, C.; Zheng, W.; Li, L.; Zheng, Y. Electrospinning of PLGA/gelatin randomly-oriented and aligned nanofibers as potential scaffold in tissue engineering. Mater. Sci. Eng. C 2010, 30, 1204-1210. [CrossRef]

157. Swindle-Reilly, K.E.; Paranjape, C.S.; Miller, C.A. Electrospun poly(caprolactone)-elastin scaffolds for peripheral nerve regeneration. Prog. Biomater. 2014, 3, 20. [CrossRef]

158. He, J.; Qin, Y.; Cui, S.; Gao, Y.; Wang, S. Structure and properties of novel electrospun tussah silk fibroin/poly(lactic acid) composite nanofibers. J. Mater. Sci. 2011, 46, 2938-2946. [CrossRef]

159. Chua, K.-N.; Chai, C.; Lee, P.-C.; Tang, Y.-N.; Ramakrishna, S.; Leong, K.W.; Mao, H.-Q. Surface-aminated electrospun nanofibers enhance adhesion and expansion of human umbilical cord blood hematopoietic stem/progenitor cells. Biomaterials 2006, 27, 6043-6051. [CrossRef]

160. Christopherson, G.T.; Song, H.; Mao, H.-Q. The influence of fiber diameter of electrospun substrates on neural stem cell differentiation and proliferation. Biomaterials 2009, 30, 556-564. [CrossRef]

161. Lim, S.H.; Liu, X.Y.; Song, H.; Yarema, K.J.; Mao, H.-Q. The effect of nanofiber-guided cell alignment on the preferential differentiation of neural stem cells. Biomaterials 2010, 31, 9031-9039. [CrossRef]

162. Xie, S.-Y.; Peng, L.-H.; Shan, Y.-H.; Niu, J.; Xiong, J.; Gao, J.-Q. Adult Stem Cells Seeded on Electrospinning Silk Fibroin Nanofiberous Scaffold Enhance Wound Repair and Regeneration. J. Nanosci. Nanotechnol. 2016, 16, 5498-5505. [CrossRef] [PubMed]

163. Tan, S.-H.; Inai, R.; Kotaki, M.; Ramakrishna, S. Systematic parameter study for ultra-fine fiber fabrication via electrospinning process. Polymer 2005, 46, 6128-6134. [CrossRef]

164. Fridrikh, S.V.; Yu, J.H.; Brenner, M.P.; Rutledge, G.C. Controlling the Fiber Diameter during Electrospinning. Phys. Rev. Lett. 2003, 90, 144502. [CrossRef] [PubMed]

165. Paterson, T.E.; Beal, S.N.; Santocildes-Romero, M.E.; Sidambe, A.T.; Hatton, P.V.; Asencio, I.O. Selective laser melting-enabled electrospinning: Introducing complexity within electrospun membranes. Proc. Inst. Mech. Eng. Part H J. Eng. Med. 2017, 231, 565-574. [CrossRef]

166. Asencio, I.O.; Mittar, S.; Sherborne, C.; Raza, A.; Claeyssens, F.; MacNeil, S. A methodology for the production of microfabricated electrospun membranes for the creation of new skin regeneration models. J. Tissue Eng. 2018, 9, 204173141879985. [CrossRef]

167. Ortega, I.; Ryan, A.J.; Deshpande, P.; MacNeil, S.; Claeyssens, F. Combined microfabrication and electrospinning to produce 3-D architectures for corneal repair. Acta Biomater. 2013, 9, 5511-5520. [CrossRef] [PubMed]

168. Kikutani, T.; Radhakrishnan, J.; Arikawa, S.; Takaku, A.; Okui, N.; Jin, X.; Niwa, F.; Kudo, Y. High-speed melt spinning of bicomponent fibers: Mechanism of fiber structure development in poly(ethylene terephthalate)/polypropylene system. J. Appl. Polym. Sci. 1996, 62, 1913-1924. [CrossRef]

169. Chung, S.; Ingle, N.P.; Montero, G.A.; Kim, S.H.; King, M.W. Bioresorbable elastomeric vascular tissue engineering scaffolds via melt spinning and electrospinning. Acta Biomater. 2010, 6, 1958-1967. [CrossRef]

170. Pelto, J.; Björninen, M.; Pälli, A.; Talvitie, E.; Hyttinen, J.; Mannerström, B.; Seppanen, R.S.; Kellomäki, M.; Miettinen, S.; Haimi, S. Novel Polypyrrole-Coated Polylactide Scaffolds Enhance Adipose Stem Cell Proliferation and Early Osteogenic Differentiation. Tissue Eng. Part A 2013, 19, 882-892. [CrossRef] 
171. Irvine, S.A.; Venkatraman, S.S. Bioprinting and Differentiation of Stem Cells. Molecules 2016, 21, 1188. [CrossRef]

172. Jakab, K.; Norotte, C.; Marga, F.; Murphy, K.; Vunjak-Novakovic, G.; Forgacs, G. Tissue engineering by self-assembly and bio-printing of living cells. Biofabrication 2010, 2, 022001. [CrossRef] [PubMed]

173. Skeldon, G.; Lucendo-Villarin, B.; Shu, W. Three-dimensional bioprinting of stem-cell derived tissues for human regenerative medicine. Philos. Trans. R. Soc. B Biol. Sci. 2018, 373, 20170224. [CrossRef] [PubMed]

174. Gao, G.; Schilling, A.F.; Yonezawa, T.; Wang, J.; Dai, G.; Cui, X. Bioactive nanoparticles stimulate bone tissue formation in bioprinted three-dimensional scaffold and human mesenchymal stem cells. Biotechnol. J. 2014, 9, 1304-1311. [CrossRef]

175. Ong, C.S.; Yesantharao, P.; Huang, C.Y.; Mattson, G.; Boktor, J.; Fukunishi, T.; Zhang, H.; Hibino, N. 3D bioprinting using stem cells. Pediatr. Res. 2018, 83, 223-231. [CrossRef] [PubMed]

176. Ovsianikov, A.; Schlie, S.; Ngezahayo, A.; Haverich, A.; Chichkov, B.N. Two-photon polymerization technique for microfabrication of CAD-designed 3D scaffolds from commercially available photosensitive materials. J. Tissue Eng. Regen. Med. 2007, 1, 443-449. [CrossRef] [PubMed]

177. Gill, A.A.; Ortega, Í.; Kelly, S.; Claeyssens, F. Towards the fabrication of artificial 3D microdevices for neural cell networks. Biomed. Microdevices 2015, 17, 27. [CrossRef] [PubMed]

178. Raimondi, M.T.; Eaton, S.M.; Laganà, M.; Aprile, V.; Nava, M.M.; Cerullo, G.; Osellame, R. Three-dimensional structural niches engineered via two-photon laser polymerization promote stem cell homing. Acta Biomater. 2013, 9, 4579-4584. [CrossRef] [PubMed]

179. Lee, H.J.; Koh, W.-G. Hydrogel Micropattern-Incorporated Fibrous Scaffolds Capable of Sequential Growth Factor Delivery for Enhanced Osteogenesis of hMSCs. ACS Appl. Mater. Interfaces 2014, 6, 9338-9348. [CrossRef] [PubMed]

180. Tallawi, M.; Dippold, D.; Rai, R.; D’Atri, D.; Roether, J.; Schubert, D.; Rosellini, E.; Engel, F.; Boccaccini, A. Novel PGS/PCL electrospun fiber mats with patterned topographical features for cardiac patch applications. Mater. Sci. Eng. C 2016, 69, 569-576. [CrossRef]

181. Lee, K.H.; Kwon, G.H.; Shin, S.J.; Baek, J.-Y.; Han, D.K.; Park, Y.; Lee, S.H. Hydrophilic electrospun polyurethane nanofiber matrices for hMSC culture in a microfluidic cell chip. J. Biomed. Mater. Res. Part A 2009, 90, 619-628. [CrossRef]

182. Ma, B.; Xie, J.; Jiang, J.; Wu, J. Sandwich-type fiber scaffolds with square arrayed microwells and nanostructured cues as microskin grafts for skin regeneration. Biomaterials 2014, 35, 630-641. [CrossRef]

183. Brunelle, A.R.; Horner, C.B.; Low, K.; Ico, G.; Nam, J. Electrospun thermosensitive hydrogel scaffold for enhanced chondrogenesis of human mesenchymal stem cells. Acta Biomater. 2018, 66, 166-176. [CrossRef] [PubMed]

184. Hennink, W.; Van Nostrum, C. Novel crosslinking methods to design hydrogels. Adv. Drug Deliv. Rev. 2012, 64, 223-236. [CrossRef]

185. Jorge-Herrero, E.; Fernández, P.; Turnay, J.; Olmo, N.; Calero, P.; García, R.; Freile, I.; Castillo-Olivares, J. Influence of different chemical cross-linking treatments on the properties of bovine pericardium and collagen. Biomaterials 1999, 20, 539-545. [CrossRef]

186. Charulatha, V. Influence of different crosslinking treatments on the physical properties of collagen membranes. Biomaterials 2003, 24, 759-767. [CrossRef]

187. Eichholz, K.F.; Hoey, D.A. Mediating human stem cell behaviour via defined fibrous architectures by melt electrospinning writing. Acta Biomater. 2018, 75, 140-151. [CrossRef]

188. Jahani, H.; Kaviani, S.; Hassanpour-Ezatti, M.; Soleimani, M.; Kaviani, Z.; Zonoubi, Z. The Effect of Aligned and Random Electrospun Fibrous Scaffolds on Rat Mesenchymal Stem Cell Proliferation. Cell J. 2012, 14, 31-38.

189. Ventre, M.; Coppola, V.; Natale, C.F.; Netti, P.A. Aligned fibrous decellularized cell derived matrices for mesenchymal stem cell amplification. J. Biomed. Mater. Res. Part A 2019, 107, 2536-2546. [CrossRef]

190. Vanderpoorten, O.; Peter, Q.; Challa, P.K.; Keyser, U.F.; Baumberg, J.; Kaminski, C.F.; Knowles, T.P.J. Scalable integration of nano-, and microfluidics with hybrid two-photon lithography. Microsyst. Nanoeng. 2019, 5, 40. [CrossRef] 